\title{
Identifying the In Vivo Cellular Correlates of Antipsychotic Drugs
}

\author{
Radhika S. Joshi ${ }^{1}$ and Mitradas M. Panicker ${ }^{1}$ \\ https://doi.org/10.1523/ENEURO.0220-18.2018 \\ ${ }^{1}$ National Centre for Biological Sciences (Tata Institute of Fundamental Research), Bengaluru 560065, India
}

\begin{abstract}
GPCRs such as 5- $\mathrm{HT}_{2 \mathrm{~A}}$ and D2 are implicated in the therapeutic and the side effects of antipsychotics. However, the pattern of brain activity that leads to the behavioral effects of antipsychotics is poorly understood. To address this question, we used the transgenic 'FosTRAP' mice (Mus musculus), where a fluorescent reporter marks the cells responsive to the stimulus of interest. Here, the stimulus was an administration of various antipsychotic drugs. In case of typical antipsychotics such as Haloperidol, the c-fos active cells were predominantly found in the striatum, whereas in case of the atypical antipsychotics (Clozapine and Olanzapine), c-fos-induced cells were more numerous in the cortical regions, e.g., orbital cortex, piriform cortex. Curiously, we also observed ependymal cells to be a novel cellular target of atypical antipsychotics. $5-\mathrm{HT}_{2 \mathrm{~A}}$ is considered to be a major target for atypical antipsychotics. Therefore, we bred 'FosTRAP' mice with 5- $\mathrm{HT}_{2 \mathrm{~A}}$ knock-out (KO) mice and tested their response to the prototype of atypical antipsychotics, Clozapine. Interestingly, the absence of $5-\mathrm{HT}_{2 \mathrm{~A}}$ did not significantly affect the number of $c$-fos-induced cells in the cortical regions. However, the ependymal cells showed a dramatically reduced response to Clozapine in the absence of $5-\mathrm{HT}_{2 \mathrm{~A}}$. In summary, the TRAP system has allowed us to identify various region-specific activity induced by antipsychotics and novel cellular targets of the antipsychotics. These results serve as a "proof of principle" study that can be extended to explore the biochemical and physiological changes brought about by antipsychotics and specifically identify antipsychoticresponsive cells in the live tissue.
\end{abstract}

Key words: 5-HT2A receptor knock-out; antipsychotics; c-Fos

\section{Significance Statement}

Antipsychotic drugs have been the first choice of treatment for mental illnesses such as schizophrenia. Thorough understanding of the cellular and neuronal targets of these drugs should deepen our understanding of the pathophysiology of the mental disorders and help the development of improved therapy. We report here the use of FosTrap mice that allowed us to label cells and brain areas that were responsive to the antipsychotic treatment. We identified brain regions such as orbital cortex, piriform cortex, and ventral-posteromedial thalamus (Vpm) as the targets of the atypical class of antipsychotics. Importantly, we also report for the first time that, ependymal cells, lining the ventricles, are targeted by the atypical antipsychotics and this effect is modulated by the $5-\mathrm{HT}_{2 \mathrm{~A}}$ receptor.

\section{Introduction}

Antipsychotics have revolutionized the treatment of mental illness from the 1950s (Hippius, 1989; Shen, 1992).
Even today, antipsychotics are the preferred treatment for schizophrenia (Roth et al., 2004; Ross et al., 2006; Leucht et al., 2009). However, the mechanism of action of antip-
Received June 3, 2018; accepted September 1, 2018; First published October 9, 2018.

The authors declare no competing financial interests.
Author contributions: R.S.J. and M.M.P. designed research; R.S.J. performed research; R.S.J. analyzed data; R.S.J. and M.M.P. wrote the paper. 
sychotics still remains unclear and controversial, and the brain areas, neural circuits and cellular targets involved in the effects of antipsychotics need to be better identified.

Binding affinities have suggested the D2 dopamine receptor and the serotonin receptor $5-\mathrm{HT}_{2 \mathrm{~A}}$ as the prime targets of antipsychotics (Roth et al., 1994, 2004; Yadav et al., 2011a). Based on the relative affinities for the $5-\mathrm{HT}_{2 \mathrm{~A}}$ and D2, antipsychotics are also classified as atypical or typical. Typical antipsychotics exhibit higher affinity for D2 than $5-\mathrm{HT}_{2 \mathrm{~A}}$ and the reverse is seen for atypical antipsychotics (Meltzer et al., 1989). Antagonism at the $5-\mathrm{HT}_{2 \mathrm{~A}}$ and D2 is thought to underlie some of the therapeutic effects and/or side effects of antipsychotics (Kapur et al., 1995, 2000; Wadenberg et al., 2000; Fribourg et al., 2011; Moreno et al., 2016). Along with the 5- $\mathrm{HT}_{2 \mathrm{~A}}$ and D2, antipsychotics can also bind to many other GPCRs with varying affinities, for example, muscarinic receptors, adrenergic receptors, and histamine receptors (Roth et al., 2004). However, the role of these GPCRs in modulating the antipsychotic-induced effects on neural circuits or cellular targets is largely unknown.

Previously, c-fos activity has been used to identify the brain areas and cells that are active on the administration of antipsychotics. Up-regulation of c-fos gene has been suggested as a marker for neuronal activity. Many stimuli have been shown to cause up-regulation of $c$-fos, for example, seizure (Morgan et al., 1987; Gunn et al., 1990), membrane depolarization (Sheng et al., 1990), and novel environment and psychoactive drugs (Day et al., 2001; Uslaner et al., 2001; Ostrander et al., 2003).

Prior studies showed that the typical and atypical antipsychotics cause increased c-fos activity in the striatum and prefrontal cortex, respectively, whereas up-regulation of $c$-fos in the nucleus accumbens was reported for both (Wan et al., 1995; Deutch and Duman, 1996; Verma et al., 2007). In these studies, c-fos activity was detected by immunohistochemistry or in situ hybridization. These techniques can be limiting due to the sensitivity and specificity of the probes. In addition, they provide limited access to cellular morphology. Since these procedures require the tissue to be fixed, they also severely compromise further biochemical and physiologic investigations.

This work was supported by Grant BT/PR10961/MED/30/1310/2014 from the Department of Biotechnology (India) and National Centre for Biological Sciences (Tata Institute of Fundamental Research).

R.S. Joshi's present address: Neurobiology Department, University of Massachusetts Medical School, Worcester, MA 01605.

M.M. Panicker's present address: Department of Physiology and Biophysics, University of California, Irvine, CA 92617.

Acknowledgements: We thank Professor Sanjeev Jain, NIMHANS, Bengaluru, India for valuable discussions. We also thank the Institutional Animal Care and Resource Centre (ACRC), National Centre for Biological Sciences (NCBS) for housing and care of animals and the Central Imaging and Flow Cytometry Facility (CIFF), NCBS for providing the infrastructure for the confocal imaging.

Correspondence should be addressed to Mitradas M. Panicker or Radhika S. Joshi, National Centre for Biological Sciences, GKVK Campus, Bellary Road, Bengaluru 560065, India, Email: panic@ncbs.res.in or radheekaj@gmail.com.

https://doi.org/10.1523/ENEURO.0220-18.2018

Copyright $\odot 2018$ Joshi and Panicker

This is an open-access article distributed under the terms of the Creative Commons Attribution 4.0 International license, which permits unrestricted use, distribution and reproduction in any medium provided that the original work is properly attributed.
In this study, we describe the activity induced by antipsychotics, using the 'FosTrap' system. This system, designed by Luo and colleagues (Guenthner et al., 2013), permanently marks cells in which $c$-fos is active following the stimulus. TRAP system requires co-administration of Tamoxifen poststimulus, as the $c$-fos promoter drives the expression of the $\mathrm{CreER}^{\mathrm{T} 2}$ recombinase. The presence of the estrogen receptor (ER) binding site allows entry of Cre recombinase into the nucleus only in the presence of Tamoxifen. Therefore, Tamoxifen, coupled with the stimulus, traps "stimulus responsive cells" to permanently express the reporter (Guenthner et al., 2013; Fig. 1A). 'FosTrap' mice have shown increased $c$-fos activity in specific areas following exposure to a novel context, whisker stimulation, light exposure, etc., which led us to try and identify cells in the brain that are activated by antipsychotics.

We tested two different antipsychotics each from the typical and atypical groups, i.e., Haloperidol, Loxapine, Clozapine, and Olanzapine. Using this system, we screened different cortical and subcortical brain areas for active $c$-fos in response to antipsychotics. In general, we observed that the typical and atypical antipsychotics showed little overlap in the area-wise pattern of activity. Brain areas such as the orbital cortex, piriform cortex, and ventral-posteromedial thalamus ( $\mathrm{Vpm}$ ) were responsive to the atypical drugs while cells in the striatal region responded to typical antipsychotics. $5-\mathrm{HT}_{2 \mathrm{~A}}$ being the major target of Clozapine, we also investigated the role of $5-\mathrm{HT}_{2 \mathrm{~A}}$ in modulating the activity pattern induced by Clozapine using an available $5-\mathrm{HT}_{2 \mathrm{~A}}$ knock-out $(\mathrm{KO})$ mice.

Our results also identified ependymal cells within the ventricles as novel cellular targets of the antipsychotics Clozapine and Olanzapine and heavily modulated by $5-\mathrm{HT}_{2 \mathrm{~A}}$. Briefly, the 'FosTrap' system has allowed us to identify live cells in brain regions which are known to be activated or modulated by typical and atypical antipsychotics as well as newer regions and cell types. The system can be used further for potential manipulation and investigation of the "trapped" cells in vivo and the circuits they are a part of.

\section{Materials and Methods}

\section{Animals}

Animals were maintained on ad libitum food and water on a 10/14 h light/dark cycle. Experiments were performed during the daytime. Males and females, minimum of eight weeks or older, were used for the experiments. FosCreER mice (c-Fos Cre ERT2 (B6.129(Cg)-Fos ${ }^{\text {tm1.1(cre/ERT2)Luo/J) }}$ and Lox-tdTomato (B6.Cg-Gt(ROSA)26Sor tm14(CAG-tdTomato Hze/J) mice were obtained from the Jackson laboratory (stock numbers 021882 and 007914, respectively) and maintained as per The Jackson laboratory guidelines. $\mathrm{Htr}^{2} \mathrm{a}^{-/-}$mice were maintained through heterozygous matings. All animal procedures were performed in accordance with the [National Centre for Biological Sciences] animal care committee's regulations.

F1 progeny of cross between FosCreER ${ }^{\mathrm{T} 2}$ mice $\left(\right.$ Fos $\left.^{\mathrm{CreER/+}}\right)$ and Lox-tdTomato $\left(R 26^{\mathrm{A} / 14 / \mathrm{A} 14}\right)$ were used for the experiments. The F1 (Fos ${ }^{\mathrm{CreER/+}} R 26^{\mathrm{Al14/+}}$ ) mice were also crossed into $\mathrm{Htr}_{2} \mathrm{a}^{-/-}$background to generate the triple transgenic mice with the genotype Fos ${ }^{\mathrm{CreER} /+}$ 
A

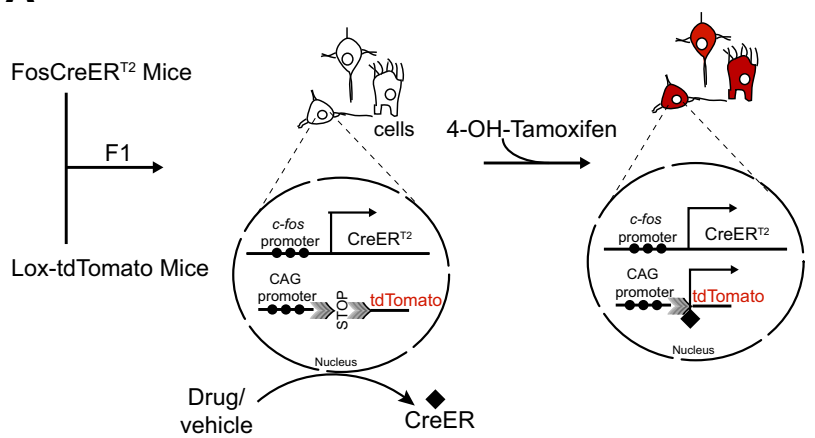

B

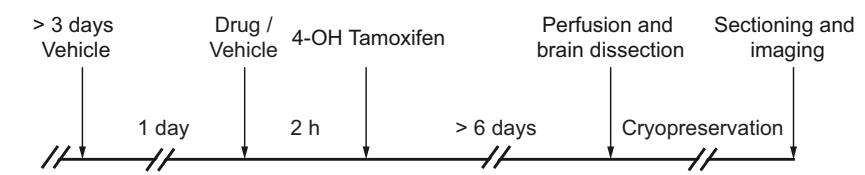

D

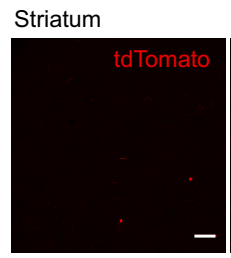

Vehicle

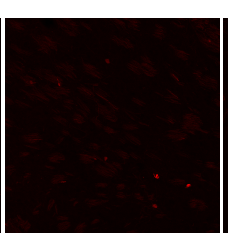

Clozapine

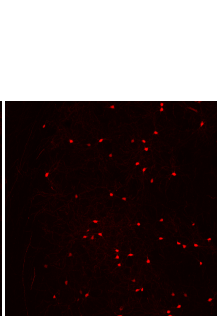

Haloperidol

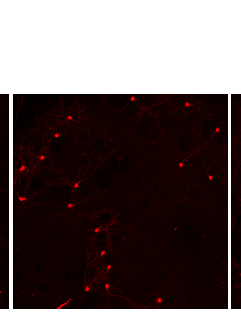

Loxapine
C
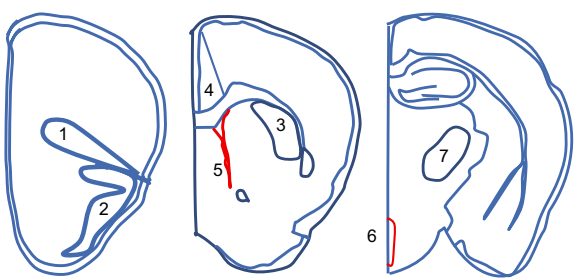

1- Orb/Orbital cortex: 2.46 to $1.98 \mathrm{~mm}$

2- Pir/ Piriform cortex: 2.46 to $1.98 \mathrm{~mm}$

3- Str/ dorsal striatum: 1.18 to $0.34 \mathrm{~mm}$

4- $\mathrm{Cg}$ / Cingulate cortex: 1.42 to $0.38 \mathrm{~mm}$

5- Ven/Lateral ventricles: 1.42 to $0.38 \mathrm{~mm}$

6- 3rd Ven/ ventricle: -1.34 to $-1.94 \mathrm{~mm}$

7- Vpm/ Ventral-posteromedial Thalamus:

-1.46 to $-1.94 \mathrm{~mm}$

Figure 1. FosTRAP mice showed increased labeling of cells by tdTomato in the striatum on treatment with antipsychotic drugs. $\boldsymbol{A}$, Schematic representation of the 'FosTRAP' system. F1 progeny of FosCreER and Lox-tdTomato mice of the genotype Fos CreER/+ $R 26^{A / 14 /+}$ are used. Neural cells that respond (mostly neuronal in morphology; see also Extended Data Fig. 1-1) express CreER ${ }^{\text {T2 }}$ recombinase, which can only enter the nucleus if bound by Tamoxifen or 4-OH-Tamoxifen. Once CreER ${ }^{\mathrm{T} 2}$ enters the nucleus it excises the STOP sequence and initiates permanent expression of tdTomato. Promoter region is indicated by solid circles. Arrowheads inside the nucleus indicate initiation and direction of transcription. Solid diamond shape denotes CreER ${ }^{\mathrm{T} 2}$, shaded arrows represent the LoxP sites. $\boldsymbol{B}$, Schematic of the experimental protocol. Antipsychotic drugs (at the concentrations indicated) or vehicle were used as the stimulus. $4-\mathrm{OH}-T a m o x i f e n$ was administered $2 \mathrm{~h}$ later. The mice were fixed by perfusion after a minimum of $6 \mathrm{~d}$. The brains were sectioned and imaged. $\boldsymbol{C}$, Schematic representation of the areas imaged. $\boldsymbol{D}$, Representative images of the tdTomato labeling induced by various antipsychotics in the dorsolateral striatum. Scale bar: 10 $\mu \mathrm{m}$. $\boldsymbol{E}$, Quantification of the number of tdTomato-positive cells per section. Haloperidol showed the maximum number of tdTomato-positive cells in the striatum, followed by Olanzapine and Loxapine. Numbers within the bars represent the number of mice examined in that group. Kruskal-Wallis test was used for statistical significance. Data represented as mean $\pm \mathrm{SEM} ; *$ $<0.05, * * * p<0.001, * * * * p<0.0001$.

R26 ${ }^{\mathrm{Al14/+}} \mathrm{Htr} 2 \mathrm{a}^{+/+}$and Fos ${ }^{\mathrm{CreER} /+} \mathrm{R}^{\mathrm{A}} 6^{\mathrm{Al14/+}} \mathrm{Htr}^{\mathrm{A}} \mathrm{a}^{-/-}$. The Fos $^{\mathrm{CreER} /+} \mathrm{R}^{2} \mathrm{6}^{\mathrm{Al14/+}} \mathrm{Htr} 2 \mathrm{a}^{-/-}$were subsequently maintained on the $\mathrm{Htr}_{\mathrm{t}} \mathrm{a}^{-/-}$background. Similarly, the Fos ${ }^{\mathrm{CreER} /}$ ${ }_{+} 26^{A / 14 /+} \mathrm{Htr}^{2} \mathrm{a}^{+/+}$mice were maintained on the $H$ tr2a $\mathrm{a}^{+/+}$background. To rule out the effect of $5-\mathrm{HT}_{2 \mathrm{~A}}$, if any, on maternal rearing, experimental results were verified on a small set of $\mathrm{Htr}_{2} \mathrm{a}^{+/+}$and $\mathrm{Htr}_{2} \mathrm{a}^{-/-}$animals obtained by heterozygous matings of Fos ${ }^{\mathrm{CreER} /+} R 26^{\mathrm{Al14/+}}$ Htr2a \pm .

All the mice were genotyped for the presence of Cre, LoxP, and the Htr2a locus.

\section{Genotyping}

Genotyping was performed using polymerase chain reactions with genomic DNA obtained from tail clips.

\section{Primers}

For Htr2a KO strain, wild-type (WT) fragment: fragment (1) $408 \mathrm{bp}$ or fragment (2) $200 \mathrm{bp}$, Htr2a mutant fragment: 642 bp.

WT forward (1), CAT GGA AAT TCT CTG TGA AGA CA; WT reverse (1), AGG ATG GTT AAC ATG GAC ACG, WT forward (2), GGT ACC GGT GGC CTT TGC C; WT reverse (2), TAC GGA TAT GGT CCA CAC CGC AAT; mutant forward, AGT TAT TAG GTC CCT CGA AGA GGT; mutant reverse, GGT ACA AGT CCT TGC TGT ACA ATG.

FosCreER mice, WT product: 215, mutant fragment: 293.

Common forward, CAC CAG TGT CTA CCC CTG GA; WT reverse, CGG CTA CAC AAA GCC AAA CT; mutant reverse, CGC GCC TGA AGA TAT AGA AGA. 
For Lox-tdTomato mice, WT fragment: 297 bp, mutant fragment: $196 \mathrm{bp}$.

WT forward, AAG GGA GCT GCA GTG GAG TA; WT reverse, CCG AAA ATC TGT GGG AAG TC; mutant reverse, GGC ATT AAA GCA GCG TAT CC; mutant forward, CTG TTC CTG TAC GGC ATG G.

\section{Drugs}

Clozapine (catalog number 0444) stock: $50 \mathrm{mg} / \mathrm{ml}$, Haloperidol (catalog number 0931) stock: $10 \mathrm{mg} / \mathrm{ml}$, and Olanzapine (catalog number 4349) stock: $50 \mathrm{mg} / \mathrm{ml}$ were from Tocris Bioscience and dissolved in DMSO. Loxapine (catalog number L106) stock: $10 \mathrm{mg} / \mathrm{ml}$ was from SigmaAldrich and dissolved in $0.9 \%$ saline. All aqueous solutions were buffered to $\mathrm{pH} \mathrm{6-6.5} \mathrm{if} \mathrm{required.} \mathrm{The} \mathrm{drugs}$ were administered intraperitoneally.

4-OH-Tamoxifen (catalog number H6278) was purchased from Sigma-Aldrich. It was prepared as described previously (Guenthner et al., 2013). Briefly, 4-OH-Tamoxifen was dissolved in ethanol at $20 \mathrm{mg} / \mathrm{ml}$ and stored at $-20^{\circ} \mathrm{C}$. $4-\mathrm{OH}-\mathrm{Tamoxifen}$ stock in ethanol was mixed with corn oil to achieve the final concentration of $10 \mathrm{mg} / \mathrm{ml}$. The ethanol was evaporated using Centrivap before injection.

\section{Mouse brain processing}

The animals were perfused with $4 \%$ paraformaldehyde (PFA) and the brains were dissected out. Brains were postfixed in 4\% PFA overnight. Following cryopreservation in $30 \%$ sucrose, the brains were sectioned into 40 $\mu \mathrm{m}$-thick slices.

\section{Antibody staining}

Anti-Vimentin antibody (catalog number ab92547) was from Abcam and the anti-S100 $\beta$ antibody (catalog number Z0311) was from Dako (Agilent Technologies); 0.3\% Triton X-100 in 3\% milk powder, prepared in PBS, was used for blocking. The sections were incubated with the primary antibody anti-Vimentin (1:300) and anti-S100 $\beta$ $(1: 500)$ overnight at $4^{\circ} \mathrm{C}$, followed by staining with the secondary antibodies.

\section{Image acquisition and analysis}

The brain slices were imaged on the Olympus FV1000, confocal microscope. Orbital cortex (bregma, 2.46-1.98 $\mathrm{mm}$ ), Piriform cortex (bregma, 2.46-1.98), Vpm (bregma, -1.46 to $-1.94 \mathrm{~mm}$ ), and the $3 \mathrm{rd}$ ventricle (bregma, -1.34 to $-1.94 \mathrm{~mm}$ ) were imaged in every third section. The cingulate cortex (bregma, 1.42-0.38 mm), dorsal striatum (caudate-putamen; bregma, $1.18-0.34 \mathrm{~mm}$ ) and lateral ventricles (bregma, 1.42-0.38 $\mathrm{mm}$ ) were examined in every sixth slice. Images were processed using ImageJ 1.47 (NIH) software and the number of cells in each image were counted using Cell profiler (Openware, Broad Institute Imaging Platform). Final data were represented as the number of cells per section averaged from all the slices in the area of interest in both hemispheres. The ependymal cells were often too closely spaced to count individual cells, therefore total intensity was counted per image and the data were plotted as unit intensity/section.

\section{Statistics}

Data are represented as mean \pm SEM. Comparison between vehicle and drug treatments were interpreted using one-way ANOVA (or Kruskal-Wallis test where appropriate) with correction for multiple comparisons. $\mathrm{Htr}^{2} \mathrm{a}^{+/+}$and $\mathrm{Htr}^{-\mathrm{a}^{-/-}}$genotypes and treatments were compared using two-way ANOVA with correction for multiple comparisons. Student's $t$ test or Mann-Whitney $U$ test was used for comparison between male and female data. The appropriate tests are indicated in the figure legends.

\section{Results}

\section{Antipsychotics cause the increase in c-fos activity in a region-specific manner}

To identify cells that respond to antipsychotics by activating c-fos we crossed FosCreER ${ }^{\mathrm{T2}}$ mice $(\mathrm{B} 6.129(\mathrm{Cg})$ -

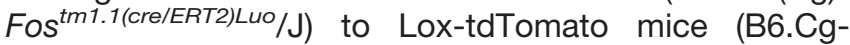
Gt(ROSA)26Sortm14(CAG-tdTomato)Hze/J) and used the F1 progeny (FOS ${ }^{\mathrm{CreER} /+} \mathrm{R} 26^{\mathrm{Al14/+}}$ mice) for the experiments (Fig. 1A). The activated cells would express tdTomato, a red fluorescent protein. Following the acute antipsychotic injection, an increase in tdTomato-positive cells was seen in various brain areas. Since the tdTomato is cytoplasmic, the entire cell could be visualized without any staining. The majority of the cells that were labeled also looked neuronal by morphology (Extended Data Fig. 1-1). We have used the term "tdTomato-positive labeling" interchangeably with c-fos activation throughout.

As mentioned earlier, previous reports show that typical antipsychotics such as Haloperidol caused activation of $c$-fos in the dorsolateral striatum. Therefore, we analyzed tdTomato labeling in the striatum first to validate our system. Dorsolateral striatum showed the highest number of tdTomato-positive cells on treatment with Haloperidol (vehicle vs Haloperidol, $p<0.0001^{\mathrm{a}}$ ). Loxapine, although considered typical antipsychotic, showed lesser numbers of activated cells in the striatum compared to Haloperidol (vehicle vs Loxapine, $p=0.0407^{\mathrm{a}}$; Fig. $1 D, E$ ). Interestingly, Olanzapine which belongs to the atypical class of antipsychotics showed a stronger c-fos response in the striatum (vehicle vs Olanzapine, $p=0.0003^{\mathrm{a}} ; 5.5$-fold over control) compared to its structural analog Clozapine but lesser than haloperidol (Fig. 1D,E). This was reproducibly observed suggesting that the labeling process was robust and antipsychotic specific.

In conclusion, the TRAP system could successfully and permanently label cells within specific brain regions in a specific antipsychotic-dependent manner. The area in which these cells were located was similar to what was expected of the typical antipsychotics based on previous literature.

\section{Cortical and thalamic subregions are more responsive to Clozapine and Olanzapine}

While Clozapine labeled the least number of cells in the striatum, certain cortical regions (Fig. 1E) were very responsive to Clozapine. Clozapine and Olanzapine caused c-fos activity patterns similar to each other in the cortical structures that we examined, unlike the 

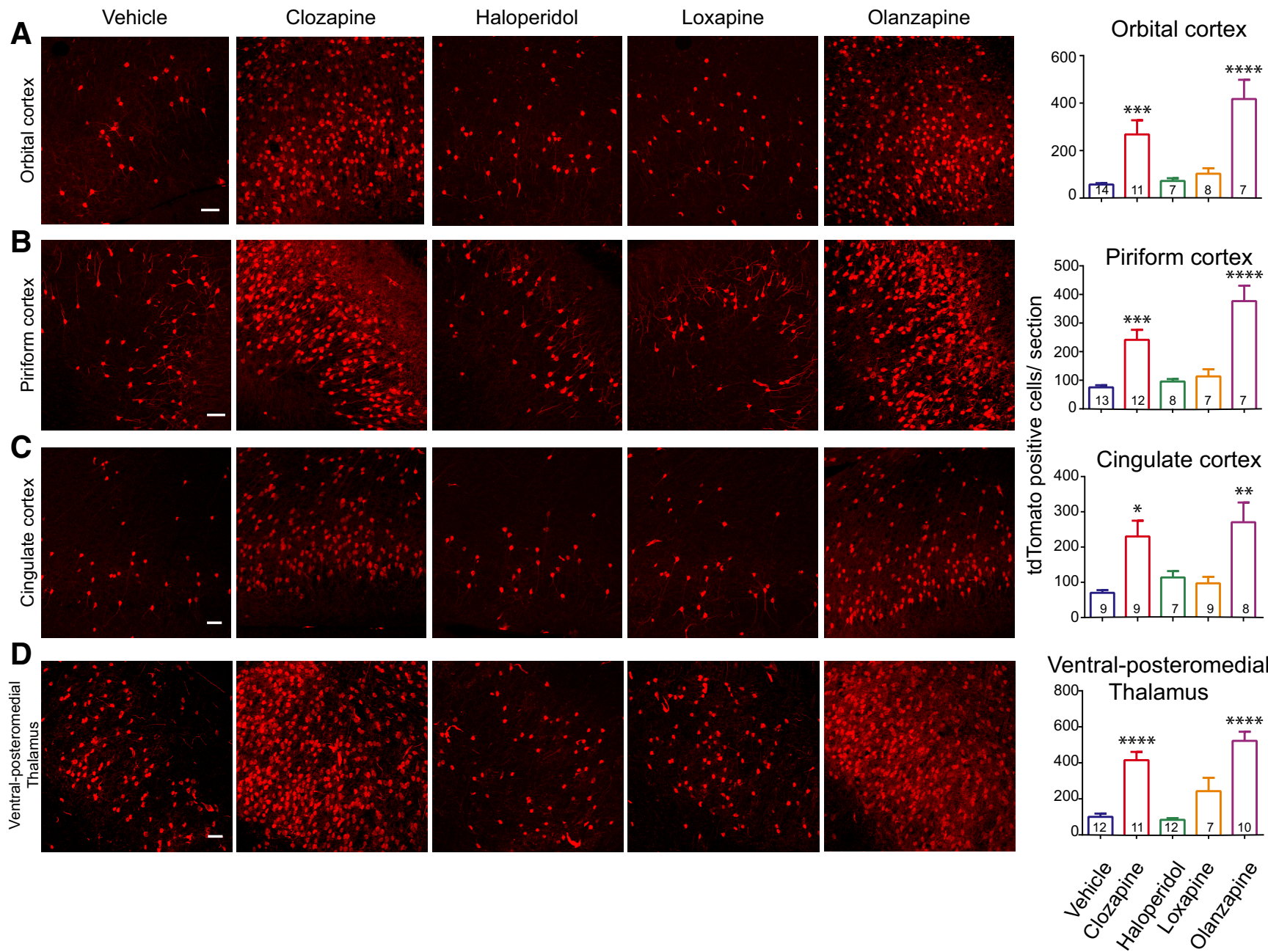

Figure 2. Clozapine and Olanzapine showed increased c-fos activity in various cortical regions and Vpm. $\boldsymbol{A}-\boldsymbol{D}$, Representative images of the tdTomato-labeled cells in the orbital cortex, piriform cortex, cingulate cortex, and Vpm. Scale bar: $10 \mu \mathrm{m}$. The graphs on the right show quantification of the number of tdTomato-positive cells per section. In all of these regions, Clozapine and Olanzapine significantly increased the number of tdTomato-positive cells compared to vehicle. The number of cells induced by Haloperidol or Loxapine was comparable to that of the vehicle. Numbers in the bars represent the number of mice examined in that group. One-way ANOVA or Kruskal-Wallis test was used. Data represented as mean $\pm \mathrm{SEM} ; * p<0.05, * * p<0.01, * * * p<0.001, * * * * p<0.0001$. See also Extended Data Figure 2-1.

striatum (Figs. 1B, 2A-C). These atypical antipsychotics caused significantly higher increases in tdTomatopositive cells in the orbital cortex (vehicle vs Clozapine, $p=0.0006$; vehicle vs Olanzapine, $p<0.0001^{\mathrm{a}}$ ), piriform cortex (vehicle vs Clozapine, $p=0.0002$; vehicle vs Olanzapine, $\left.p<0.0001^{\mathrm{a}}\right)$, and anterior cingulate cortex (vehicle vs Clozapine, $p=0.01$; vehicle vs Olanzapine, $p=0.0027^{\mathrm{a}}$ ), compared to the vehicle. In these brain areas, the number of tdTomato-positive cells induced by Haloperidol and Loxapine was comparable to the vehicle.

Previous studies have reported higher Clozapineinduced c-fos activity in the cortical regions (Deutch and Duman, 1996; Ohashi et al., 2000; Verma et al., 2007); however, c-fos activity in the orbital cortex and piriform cortex had not been reported.

Along with the cortical regions, $c$-fos activity was also noticeable in the Vpm (Figs. 1B, 2D). Clozapine and Olan- zapine showed higher numbers of tdTomato-positive cells in the Vpm compared to vehicle (vehicle vs Clozapine, $p<$ 0.0001 ; vehicle vs Olanzapine, $p<0.0001^{\mathrm{a}}$ ). Vpm is a part of thalamus which relays oral and facial sensory information to the somatosensory cortex. There are a few reports of antipsychotic-induced c-fos activity in the thalamus (Cohen, 1995; Deutch et al., 1995; Rajkumar et al., 2013), although antipsychotic-induced $c$-fos responses have not been reported in Vpm.

Most of the behavioral or biochemical studies have used only male mice, and the responses of female mice remain largely undetermined. Therefore, in this study, we also analyzed the antipsychotic-induced $c$-fos responses in male as well as female mice. We systematically compared c-fos activity in various brain regions between males and females. We did not observe any genderspecific difference in any of the regions tested (Extended Data Fig. 2-1A,B) with either Clozapine or vehicle treat- 

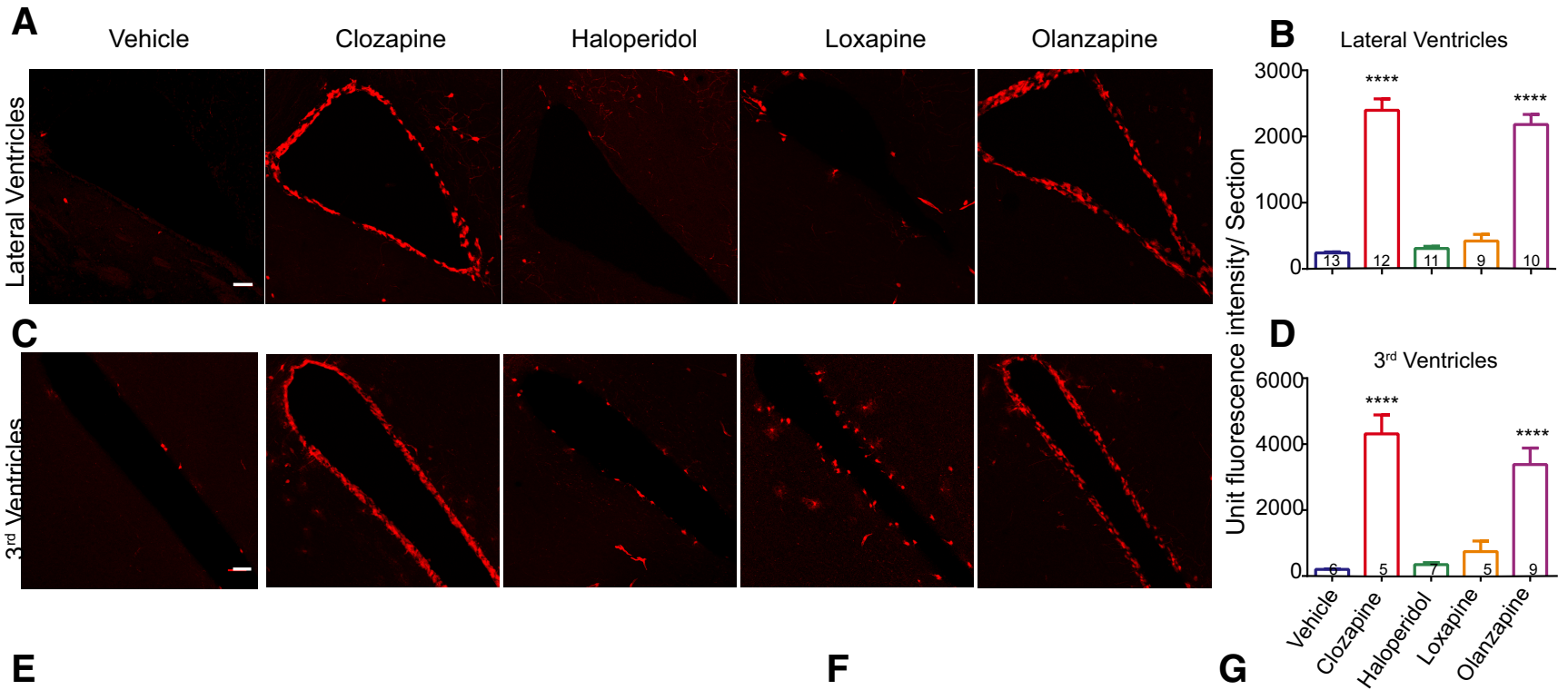

$\mathbf{E}$

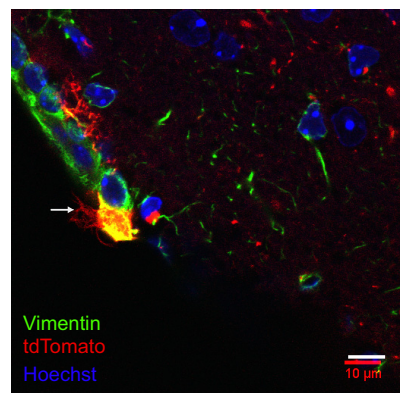

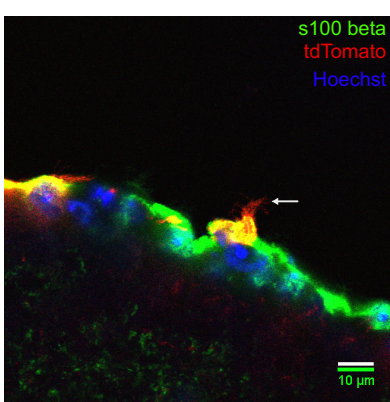

$\mathbf{F}$

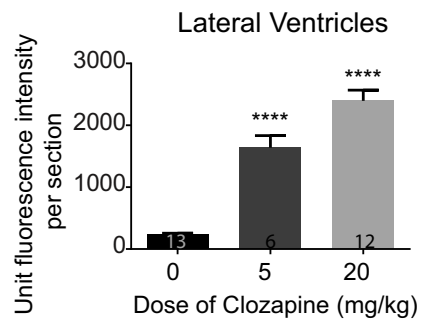

$3^{\text {rd }}$ Ventricle

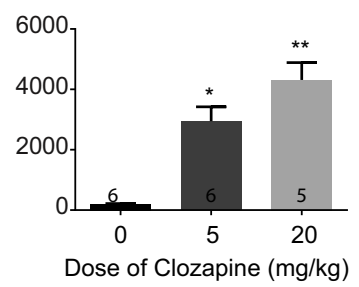

Figure 3. Ependymal cells were a novel cellular target of Clozapine and Olanzapine. $\boldsymbol{A}, \boldsymbol{C}$, Representative images of the tdTomatopositive labeling along the lateral ventricles and the 3rd ventricle, on treatment with various antipsychotics or vehicle. Scale bar: 10 $\mu \mathrm{m}$. tdTomato fluorescence within cells were seen on treatment with Clozapine and Olanzapine. $\boldsymbol{B}, \boldsymbol{D}$, Quantification of the tdTomato fluorescence in cells lining the ventricles. Clozapine and Olanzapine showed significantly more fluorescence compared to vehicle. Haloperidol and Loxapine-induced c-fos activity along the ventricles were not significantly different from that of the vehicle. Numbers in the bars represent the number of mice examined in the group. One-way ANOVA or Kruskal-Wallis test, as appropriate, was used. $\boldsymbol{E}$, tdTomato-positive cells lining the ventricles showed multiple cilia and stained positive for markers of ependymal cells (see also Extended Data Fig. 3-1). White arrows point toward ciliated structures. Scale bar: $10 \mu \mathrm{m}$. F, G, Graphs represent dose response to Clozapine. Cells lining the ventricles showed significantly higher tdTomato-positive labeling even at $5 \mathrm{mg} / \mathrm{kg}$ dose of Clozapine. Numbers in the bars represent the number of mice examined. One-way ANOVA or Kruskal-Wallis test, as appropriate, was used. Data represented as mean $\pm \mathrm{SEM} ; * p<0.05, * * p<0.01, * * * * p<0.0001$

ment. Hence, females were also included in the subsequent experiments and analysis.

Since antipsychotic effects are dose dependent, we analyzed the dose response to Clozapine. Previously, significant differences in Clozapine-induced sedation between $\mathrm{Htr} 2 \mathrm{a}^{+/+}$and $\mathrm{Htr}_{2} \mathrm{a}^{-/-}$mice have been reported at 5 $\mathrm{mg} / \mathrm{kg}$ (McOmish et al., 2012; Joshi et al., 2017), whereas doses of Clozapine around $20 \mathrm{mg} / \mathrm{kg}$ have been used very extensively to assess Clozapine-induced $c$-fos responses (Wan et al., 1995; Deutch and Duman, 1996; Badiani et al., 1999). Therefore, we tested 0, 5, and $20 \mathrm{mg} / \mathrm{kg}$ of Clozapine. At $5 \mathrm{mg} / \mathrm{kg}$ of Clozapine, most brain regions showed a trend toward increased c-fos activity (Extended Data Fig. 2-1C,F). However, at the higher dose of $20 \mathrm{mg} / \mathrm{kg}$, Clozapine significantly increased the number of tdTomato-positive cells in the cortical regions. Doses of the other antipsychotics that we tested were chosen based on the previous literature on behavioral and biochemical effects of these drugs (Deutch and Duman, 1996; Robertson and Fibiger, 1996; Cope et al.,
2005; orbital cortex: vehicle vs Clozapine $20 \mathrm{mg} / \mathrm{kg}, p=$ 0.0005; piriform cortex: vehicle vs Clozapine $20 \mathrm{mg} / \mathrm{kg}, p<$ 0.0001; cingulate cortex: vehicle vs Clozapine $20 \mathrm{mg} / \mathrm{kg}, p=$ 0.0130; Vpm: vehicle vs Clozapine $5 \mathrm{mg} / \mathrm{kg}, p=0.0147$, vehicle vs Clozapine $20 \mathrm{mg} / \mathrm{kg}, p<0.0001^{\mathrm{a}}$ ).

\section{Ependymal cells are a novel cellular target of Clozapine and Olanzapine}

Among the areas that showed c-fos expression with atypical antipsychotics were the ventricular regions. We observed consistent tdTomato labeling along the ventricles in Clozapine and Olanzapine-treated animals. This labeling was observed in the lateral ventricles as well as the 3 rd ventricle (Fig. $3 A-D$ ) and the 4 th ventricle (data not shown; lateral ventricles: vehicle vs Clozapine $p<0.0001$, vehicle vs Olanzapine $p<0.0001$; 3rd ventricles: vehicle vs Clozapine $p<0.0001$, vehicle vs Olanzapine $p<$ $\left.0.0001^{\mathrm{a}}\right)$. Haloperidol and Loxapine showed very little labeling along the ventricles (Fig. $3 A-D$ ). Curiously, the 
cells lining the ventricles were more responsive to lower doses of Clozapine than the cortical regions and showed significantly higher responses even at $5 \mathrm{mg} / \mathrm{kg}$ of Clozapine (Fig. 3F,G; lateral ventricle: vehicle vs Clozapine 5 $\mathrm{mg} / \mathrm{kg} p<0.0001$, vehicle vs Olanzapine $p<0.0001$; 3rd ventricle: vehicle vs Clozapine $5 \mathrm{mg} / \mathrm{kg} p=0.0 .0328$, vehicle vs Olanzapine $p=0.0015^{\mathrm{a}}$ ).

Atypical antipsychotics have been shown to stimulate neurogenesis in the subventricular zone, the subgranular zone in the hippocampus and in the cortex (Wakade et al., 2002; Halim et al., 2004; Kodama et al., 2004; Wang et al., 2004). Therefore, we considered the possibility that the tdTomato-positive cells lining the ventricles could be the neural stem cells. However, under high magnification these cells showed multiple cilia (Extended Data Fig. 3-1; Fig. 3E), suggesting that these were ependymal cells (Brightman and Palay, 1963; Del Bigio, 1995; Jiménez et al., 2014). Additionally, these cells stained positive for the ependymal cell marker Vimentin and $\mathrm{S} 100 \beta$ (Fig. 3E; Didier et al., 1986; Bruni, 1998; Schnitzer et al., 1981). Therefore, we conclude that these were ependymal cells and are novel cellular targets of the atypical antipsychotics that we tested.

\section{The absence of $5-\mathrm{HT}_{2 \mathrm{~A}}$ does not alter the number of tdTomato-positive cells in the cortical and thalamic region}

5- $\mathrm{HT}_{2 \mathrm{~A}}$ has been considered an important target for the therapeutic efficacy of Clozapine seen in mouse models of schizophrenia (Fribourg et al., 2011; Schmid et al., 2014; Moreno et al., 2016). 5- $\mathrm{HT}_{2 \mathrm{~A}}$ expression has been reported in the various regions of cortex such as piriform cortex, orbital cortex, cingulate cortex, etc. (Xu and Pandey, 2000; Miner et al., 2003). 5- $\mathrm{HT}_{2 \mathrm{~A}}$ levels are also reported to increase in postmortem brain (cortical) samples of drug naïve schizophrenic patients (GonzálezMaeso et al., 2008; Muguruza et al., 2013) and chronic treatment with Clozapine reduces levels of $5-\mathrm{HT}_{2 \mathrm{~A}}$ in patients and animal models (Yadav et al., 2011b; Muguruza et al., 2013). Therefore, we examined whether the $5-\mathrm{HT}_{2 \mathrm{~A}}$ receptor would modulate the observed pattern of $c$-fos activity with Clozapine. We crossed $\mathrm{Htr}^{-\mathrm{a}^{-/}}$mouse strain (obtained from Joshi et al., 2017) into the FosCreER ${ }^{\text {T2 }}$

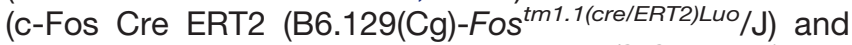

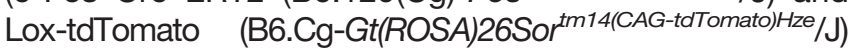
background.

We observed that Clozapine-induced c-fos activity in the cortical and thalamic regions was largely unaffected in the $\mathrm{Htr}^{2} \mathrm{a}^{-/-}$background, at both the doses tested, 5 and $20 \mathrm{mg} / \mathrm{kg}$ (Fig. $4 A-D$ ). This suggested that $5-\mathrm{HT}_{2 \mathrm{~A}}$ had minimal or no role in determining the number of tdTomatopositive neurons in response to Clozapine, in these regions. This result was surprising especially considering that these cortical areas are known to express $5-\mathrm{HT}_{2 \mathrm{~A}}$. This would suggest that the $c$-fos activity resulting in tdTomato-positive cells in the cortex arise from the complex circuitry and are not derived from direct interactions between $5-\mathrm{HT}_{2 \mathrm{~A}}$ and Clozapine (orbital cortex: WT, vehicle vs Clozapine $20 \mathrm{mg} /$ $\mathrm{kg}, p=0.0005 ; \mathrm{KO}$, vehicle vs Clozapine $20 \mathrm{mg} / \mathrm{kg}, p=$ 0.0055; piriform cortex: WT, vehicle vs Clozapine $20 \mathrm{mg} / \mathrm{kg}$, $p=0.0003 ; \mathrm{KO}$, vehicle vs Clozapine $20 \mathrm{mg} / \mathrm{kg}, p=0.0028$; cingulate cortex: WT, vehicle vs Clozapine $20 \mathrm{mg} / \mathrm{kg}, p=$ 0.0023; KO, vehicle vs Clozapine $20 \mathrm{mg} / \mathrm{kg}, p=0.0210$; Vpm; WT, vehicle vs Clozapine 20 mg/kg, $p<0.0001$; KO, vehicle vs Clozapine $20 \mathrm{mg} / \mathrm{kg}, p=0.0210^{\mathrm{a}}$ ).

\section{Clozapine-induced tdTomato labeling in the ependymal cells is modulated by $5-\mathrm{HT}_{2 \mathrm{~A}}$}

Unlike the rest of the brain regions, Clozapine-induced tdTomato labeling of ependymal cells was dramatically diminished in the Htr2a $\mathrm{a}^{-/-}$mice even at $5 \mathrm{mg} / \mathrm{kg}$ of Clozapine (Fig. $5 A, B$ ). On increasing the dose to $20 \mathrm{mg} / \mathrm{kg}$, labeling of the ependymal cells was observed in the $H \mathrm{tr} \mathrm{a}^{-/-}$mice and was statistically indistinguishable from the numbers observed in $\mathrm{Htr}_{\mathrm{t}} \mathrm{a}^{+/+}$mice (Fig. $5 \mathrm{C}, \mathrm{D}$ ). These data suggest that the genetic deletion of $5-\mathrm{HT}_{2 \mathrm{~A}}$ receptor modulates the Clozapine-induced c-fos activity in the ependymal cells, even at low doses of Clozapine (lateral ventricle: WT, vehicle vs Clozapine $5 \mathrm{mg} / \mathrm{kg}, p=0.0003$, vehicle vs Clozapine $20 \mathrm{mg} / \mathrm{kg}, p<0.0001 ; \mathrm{KO}$, vehicle vs Clozapine $20 \mathrm{mg} / \mathrm{kg}, p=0.0043$, WT vs KO at Clozapine $5 \mathrm{mg} / \mathrm{kg}, p=0.0003$; 3rd ventricle; WT, vehicle vs Clozapine $5 \mathrm{mg} / \mathrm{kg}, p=0.0134$, vehicle vs Clozapine 20 $\mathrm{mg} / \mathrm{kg}, p=0.0006 ; \mathrm{KO}$, vehicle vs Clozapine $20 \mathrm{mg} / \mathrm{kg}$, $p=0.0226$; WT vs $\mathrm{KO}$ at Clozapine $5 \mathrm{mg} / \mathrm{kg}, p=$ $\left.0.0270^{\mathrm{a}}\right)$.

In summary, the FosTrap system has led to the identification of brain areas such as orbital cortex, piriform cortex, Vpm, etc., as areas where c-fos gets consistently and reproducibly induced by the antipsychotics, Clozapine and Olanzapine. The labeled cells are neuronal and can be potentially accessed "live." Furthermore, we observed, with some surprise, that absence $5-\mathrm{HT}_{2 \mathrm{~A}}$ did not alter the number of tdTomato-positive cells at low or high doses of atypical antipsychotics in cortical or thalamic regions that were tested. However, a clear and dosedependent effect on the tdTomato labeling of ependymal cells was seen with these drugs. To the best of our knowledge, this is the first report of the effect of antipsychotics on ependymal cells.

\section{Discussion}

A thorough understanding of the mechanism of existing antipsychotics holds the key to develop safer and effective drugs. The pharmacology of the available antipsychotics has been studied quite well, although the neural correlates of these need more investigation. In this study, we have addressed a part of this issue and opened a new approach using the FosTrap system devised by Luo and colleagues (Guenthner et al., 2013).

Our experiments have already provided novel information as well as corroborated some of the available results. Haloperidol-induced $c$-fos activity in the striatum has been reported before. This activity has also been attributed to its D2 antagonism and the cataleptic side effect induced by Haloperidol (Kapur et al., 1995, 2000; Wadenberg et al., 2000). In addition to the typical antipsychotics that we tested (Haloperidol and Loxapine), Olanzapine also showed induction of $c$-fos in the striatum. This was a surprising finding owing to the atypical classification of Olanzapine. However, some studies have reported cata- 

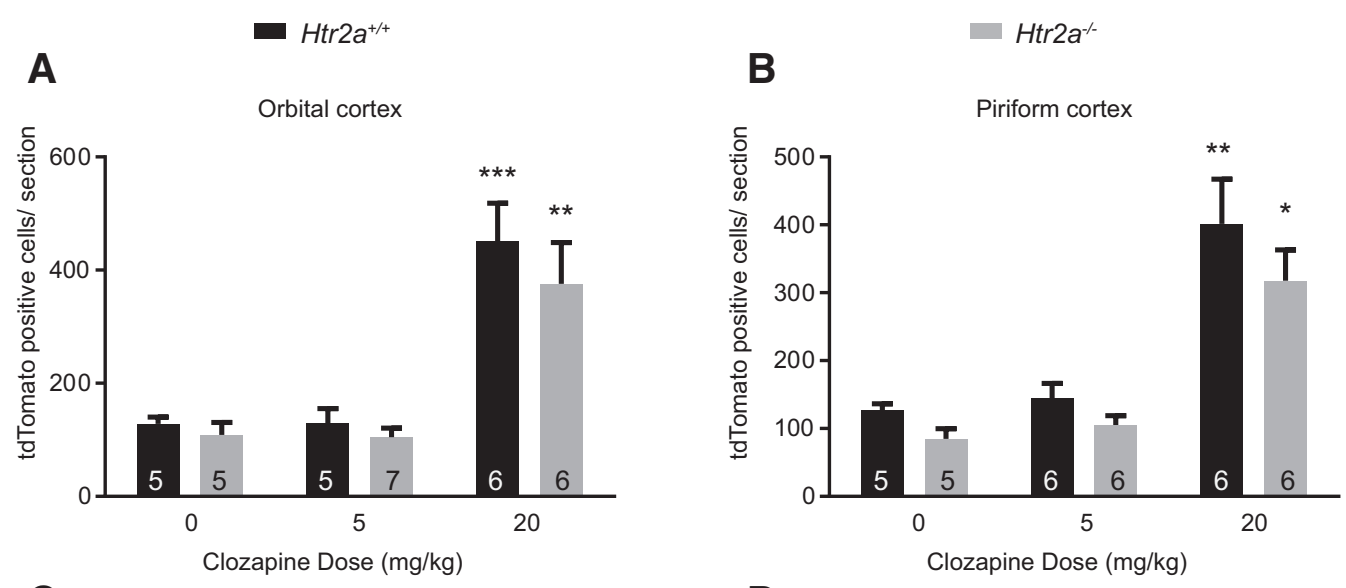

C

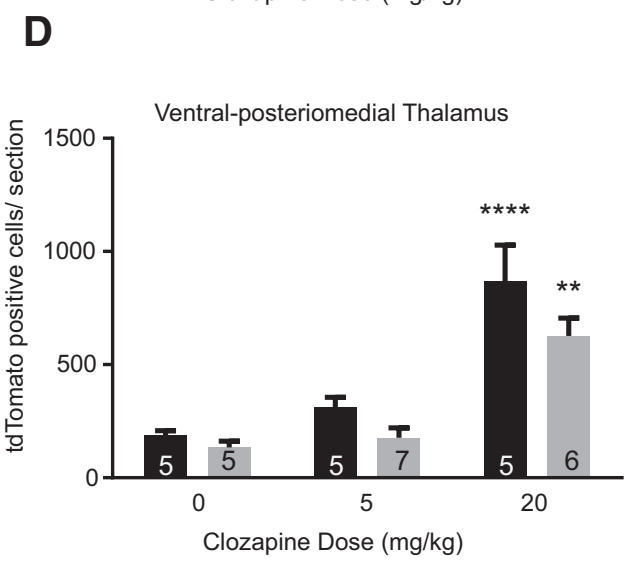

Figure 4. Clozapine-induced $c$-fos activity in the cortical regions and Vpm was largely intact in the $H_{t r 2 a^{-/-}}$mice. $\boldsymbol{A}-\boldsymbol{D}, H$ tr2a $a^{+/+}$and $\mathrm{Htr}_{2 \mathrm{a}} \mathrm{F}^{-/}$mice were not different in the number of $\mathrm{c}$-fos-positive cells in the orbital cortex, cingulate cortex, piriform cortex, and Vpm, at 5 or $20 \mathrm{mg} / \mathrm{kg}$. Numbers in the bars represent the number of mice examined in that group. Two-way ANOVA was used. Data are represented as mean \pm SEM. * comparison between vehicle and treatment for the same genotype. \# represents the comparison between WT and mutant under the same conditions; $* p<0.05, * * p<0.01, * * * p<0.001, * * * *<<0.0001$.

lepsy induced by Olanzapine in animal models (Kalkman et al., 1997; Ahlqvist et al., 2003).

A parsimonious and widely-accepted explanation for the pattern of antipsychotic-induced activity in the striatum (Fig. 1D) is based on the relative affinities of these drugs to the receptors. As mentioned above, D2 antagonism is thought to promote catalepsy, whereas $5-\mathrm{HT}_{2 \mathrm{~A}}$ antagonism is thought to improve catalepsy-like behavior (Ansah et al., 2011; Creed-Carson et al., 2011). The balance of affinities for $\mathrm{D} 2$ and $5-\mathrm{HT}_{2 \mathrm{~A}}$ may indeed determine the $c$-fos activity in the striatum. Among the four antipsychotics tested, Haloperidol has the highest affinity for D2 and Clozapine the least. Olanzapine and Loxapine have 10-fold more affinity for D2 than Clozapine and more affinity for $5-\mathrm{HT}_{2 \mathrm{~A}}$ than Haloperidol (Roth et al., 2004).

Clozapine and Olanzapine-induced increases in c-fos activity in the cortical areas have useful implications, particularly because these regions have been associated with the pathophysiology of schizophrenia and other mental disorders. For example, reduction in gray matter in the anterior cingulate cortex and orbitofrontal cortex has been observed in postmortem samples of schizophrenia patients (Pantelis et al., 2003; Fornito et al., 2009). Reduction in the volume of olfactory bulb and deficits in the olfactory capacity have also been reported (Moberg et al., 1999;
Turetsky et al., 2000). Moreover, these cortical areas have been associated with cognitive functions such as reward learning, decision-making (Rushworth et al., 2011), working memory (Barbey et al., 2011), etc., c-fos activity in the piriform cortex has also been associated with antidepressant effects (Sibille et al., 1997). Therefore, c-fos induction in these brain regions may indeed correlate with the effect of antipsychotics on the negative symptoms and the cognitive symptoms of schizophrenia.

Antipsychotic-induced increased c-fos activity in the Vpm is a novel finding. Hallucinogens such as LSD and $\mathrm{DOI}, 5-\mathrm{HT}_{2 \mathrm{~A}}$ agonists, have been shown to bring about hallucinogen-specific gene regulation in the somatosensory cortex (González-Maeso et al., 2003). Therefore, the increased $c$-fos activity in the Vpm, in response to Clozapine and Olanzapine, may be related to the circuitry underlying modulation by antipsychotics in the somatosensory cortex.

Certain behavioral effects of atypical antipsychotics, for example, sedation, are shown to be dependent on $5-\mathrm{HT}_{2 \mathrm{~A}}$ (McOmish et al., 2012; Williams et al., 2012; Joshi et al., 2017), while other biochemical effects are reported to be independent of 5- $\mathrm{HT}_{2 \mathrm{~A}}$ (Bortolozzi et al., 2010; Yadav et al., 2011a). Taking into account the high affinity of Clozapine for $5-\mathrm{HT}_{2 \mathrm{~A}}$ and receptor's expression in the cortex, we expected Clozapine to show a significant de- 
A

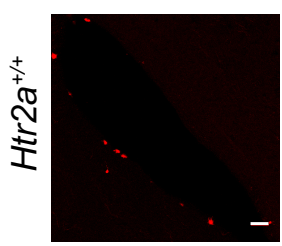

Lateral Ventricles
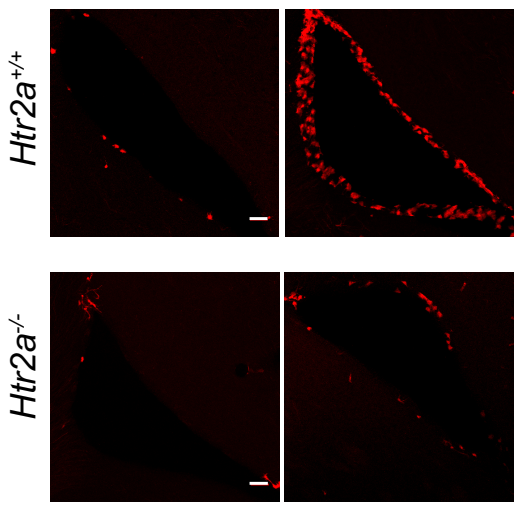
$\begin{array}{cc}\text { Clozapine } & 0 \\ \text { dose }(\mathrm{mg} / \mathrm{kg}) & \end{array}$

C

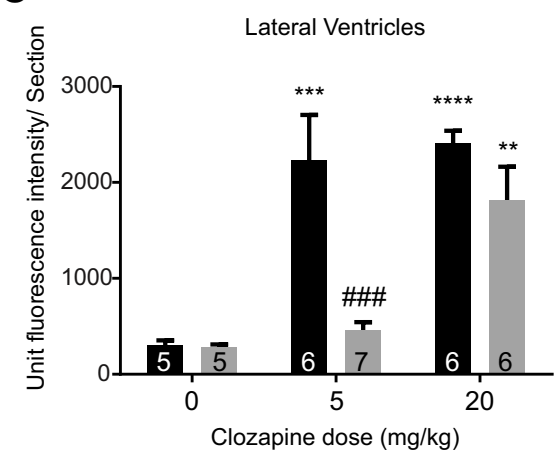

B
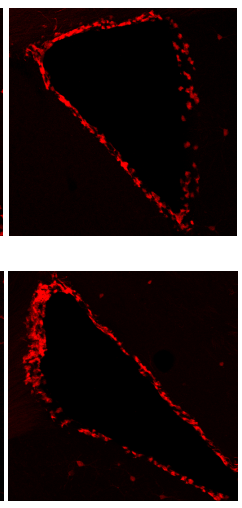

20

5

D

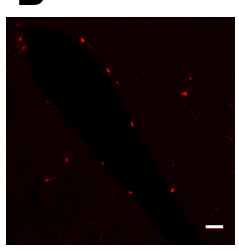

3rd Ventricles

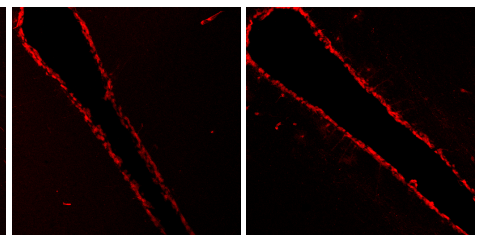

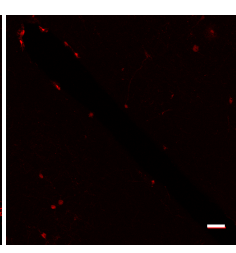

0

D

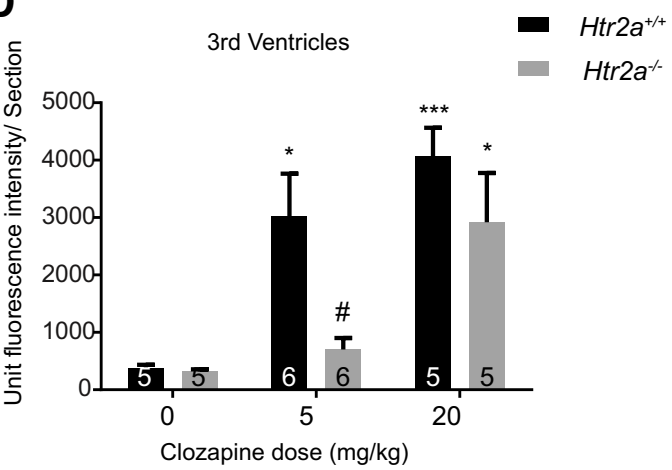

Figure 5. Clozapine-induced $c$-fos activity in the ependymal cells was diminished by deletion of $5-\mathrm{HT}_{2 \mathrm{~A}}$. $\boldsymbol{A}, \boldsymbol{B}, \mathrm{Representative} \mathrm{images}$ of the lateral ventricles and the $3 \mathrm{rd}$ ventricles. tdTomato labeling was strikingly diminished in the $\mathrm{Htr} 2 \mathrm{a}^{-/-}$mice at $5 \mathrm{mg} / \mathrm{kg}$ of Clozapine. However, at $20 \mathrm{mg} / \mathrm{kg}$ of Clozapine increased levels of activity were seen. Scale bar: $10 \mu \mathrm{m}$. $\boldsymbol{C}, \boldsymbol{D}$, The lateral and the $3 \mathrm{rd}$ ventricles showed reduced tdTomato fluorescence at $5 \mathrm{mg} / \mathrm{kg}$ in the $\mathrm{Htr}_{2} \mathrm{a}^{-/-}$mice compared to the Htr2a $\mathrm{a}^{+/+}$. Fluorescence levels were not statistically different between the $\mathrm{Htr}_{2} \mathrm{a}^{+/+}$and $\mathrm{Htr}_{2} \mathrm{a}^{-/-}$mice at $20 \mathrm{mg} / \mathrm{kg}$ of Clozapine. Numbers in the bars represent the number of mice assayed in that group. Two-way ANOVA was used for statistical significance. Data are represented as mean \pm SEM. $*$ comparison between vehicle and treatment for the same genotype. \# represents the comparison between WT and mutant under the same conditions; $* p<0.05, * * p<0.01$, $* * * p<0.001$, $* * * * p<0.0001$.

crease in the number of tdTomato-positive cells in the cortical areas in $\mathrm{Htr} 2 \mathrm{a}^{-/-}$mice. Surprisingly, the response of Clozapine, in the number of tdTomato-positive cells, was statistically indistinguishable in the cortical areas and the Vpm, between the $\mathrm{Htr}_{2} \mathrm{a}^{-/-}$and $\mathrm{Htr}_{\mathrm{tr}} \mathrm{a}^{+/+}$backgrounds. This suggests that the increase in c-fos activity in the cortical areas due to atypical antipsychotics is $5-\mathrm{HT}_{2 \mathrm{~A}}$ independent and perhaps likely due to the interaction of the antipsychotics with other receptors. It would certainly be of interest to determine the strength of the response and any variation in the transcriptome of the "tdTomatopositive cells" in the absence of $5-\mathrm{HT}_{2 \mathrm{~A}}$; however, it is beyond the scope of the current report. The strength of the response in the TRAP system is limited to the number of cells activated, and it is not designed to report on the levels of c-Fos in the cell.

In our system, we saw c-fos activity predominantly in cells with neuronal morphology, except in case of the ependymal cells. Antipsychotic-induced activation of the ependymal cells is an important finding from this study. This finding is novel and particularly intriguing because of the functional properties of this multiciliated cell type.
Ependymal cells play crucial role in cortical development (Jiménez et al., 2014). Ependymal cells form a barrier between CSF and brain tissue and are involved in diverse functions such as the production and circulation of CSF (Nelson and Wright, 1974; Nielsen et al., 1997; Tissir et al., 2010) and transport of water molecules (Nielsen et al., 1997; Jiménez et al., 2014). Ciliopathies are associated with mental retardation and neurodevelopmental disorders (Lee and Gleeson, 2011). Moreover, several genes underlying neuropsychiatric disorders, have been found to be localized to or involved in the formation and maintenance of primary cilia, for example, schizophreniaassociated gene DISC1 (Marley and von Zastrow, 2010, 2012). c-fos activity in ependymal cells has been reported in response to formalin-induced acute pain (Palkovits et al., 2007), posthypoxia seizures (Gunn et al., 1990), and on treatment with the antidepressants such as Rolipram (Dragunow and Faull, 1989). Importantly, ependymal cells also provide a niche for neural stem cells (Lim et al., 2000; Tramontin et al., 2003; Luo et al., 2008). Thus, our results are particularly intriguing in light of the role of the " $5-\mathrm{HT}_{2 \mathrm{~A}}$ 
Table 1: Table of statistics

\begin{tabular}{|c|c|c|c|c|c|c|}
\hline Figure & Data structure & Type of test & Confidence interval & Upper & Lower & Mean ranks \\
\hline \multirow[t]{5}{*}{$(1 E$, Cpu } & Not normal & Kruskal- Wallis test & Vehicle & & & 5 \\
\hline & & & Clozapine & & & 16.86 \\
\hline & & & Haloperidol & & & 34.78 \\
\hline & & & Loxapine & & & 21.2 \\
\hline & & & Olanzapine & & & 30.71 \\
\hline \multirow[t]{5}{*}{$2 A$, Orb } & Not normal & Kruskal- Wallis test & Vehicle & & & 14.14 \\
\hline & & & Clozapine & & & 38.18 \\
\hline & & & Haloperidol & & & 19.57 \\
\hline & & & Loxapine & & & 22.13 \\
\hline & & & Olanzapine & & & 45.57 \\
\hline \multirow[t]{5}{*}{$2 B$, Pir } & Normal & One-way ANOVA & Vehicle - Clozapine 20 mg/kg & -71.0245 & -261.449 & \\
\hline & & & Vehicle - Haloperidol $1 \mathrm{mg} / \mathrm{kg}$ & 86.82508 & -126.926 & \\
\hline & & & Vehicle - Loxapine 1.5 mg/kg & 73.44772 & -149.555 & \\
\hline & & & Vehicle - Olanzapine $16 \mathrm{mg} / \mathrm{kg}$ & -192.978 & -415.981 & \\
\hline & & & Vehicle - Clozapine 5 mg/kg & 53.0639 & -181.707 & \\
\hline \multirow[t]{5}{*}{$2 C, \mathrm{Cg}$} & Not normal & Kruskal- Wallis test & Vehicle - Clozapine 20 mg/kg & -33.2025 & -307.102 & \\
\hline & & & Vehicle - Haloperidol $1 \mathrm{mg} / \mathrm{kg}$ & 103.291 & -189.52 & \\
\hline & & & Vehicle - Loxapine 1.5 mg/kg & 110.014 & -163.885 & \\
\hline & & & Vehicle - Olanzapine 16 mg/kg & -59.3778 & -341.707 & \\
\hline & & & Vehicle - Clozapine 5 mg/kg & 40.4602 & -265.769 & \\
\hline \multirow[t]{5}{*}{$2 D, \mathrm{Vpm}$} & Normal & One-way ANOVA & Vehicle - Clozapine 20 mg/kg & -147.234 & -436.742 & \\
\hline & & & Vehicle - Haloperidol $1 \mathrm{mg} / \mathrm{kg}$ & 162.7995 & -120.346 & \\
\hline & & & Vehicle - Loxapine $1.5 \mathrm{mg} / \mathrm{kg}$ & 22.91145 & -306.942 & \\
\hline & & & Vehicle - Olanzapine 16 mg/kg & -271.852 & -568.817 & \\
\hline & & & Vehicle - Clozapine 5 mg/kg & -1.71831 & -331.572 & \\
\hline \multirow[t]{5}{*}{$3 B$, lateral ven } & Not normal & Kruskal- Wallis test & Vehicle & & & 13.62 \\
\hline & & & Clozapine & & & 45.58 \\
\hline & & & Haloperidol & & & 18.91 \\
\hline & & & Loxapine & & & 19.56 \\
\hline & & & Olanzapine & & & 43.2 \\
\hline \multirow[t]{5}{*}{$3 D$, 3rd ven } & Normal & One-way ANOVA & Control - Clozapine 20 mg/kg & -2882.17 & -5970.32 & \\
\hline & & & Control - Haloperidol $1 \mathrm{mg} / \mathrm{kg}$ & 1244.376 & -1592.95 & \\
\hline & & & Control - Loxapine 1.5 mg/kg & 1004.714 & -2083.43 & \\
\hline & & & Control - Olanzapine 16 mg/kg & -1947.88 & -4635.77 & \\
\hline & & & Control - Clozapine 5 mg/kg & -1272.19 & -4216.62 & \\
\hline \multirow[t]{2}{*}{$3 F$, dose response, lateral ven } & Normal & One-way ANOVA & Vehicle - Clozapine 5 mg/kg & -906.076 & -1881.76 & \\
\hline & & & Vehicle - Clozapine 20 mg/kg & -1754.7 & -2546.08 & \\
\hline \multirow[t]{3}{*}{$3 G$, dose response, 3 rd ven } & Not normal & Kruskal- Wallis test & Vehicle & & & 3.5 \\
\hline & & & Clozapine 5 mg/kg & & & 10.5 \\
\hline & & & Clozapine $20 \mathrm{mg} / \mathrm{kg}$ & & & 13.8 \\
\hline \multirow[t]{7}{*}{$4 A$, Orb } & Normal & Two-way ANOVA & Clozapine 0 mg/kg:Htr2a ${ }^{+/+}$- Clozapine 0 mg/kg:Htr2a ${ }^{-/-}$ & 239.4678 & -200.334 & \\
\hline & & & Clozapine 0 mg/kg:Htr2a ${ }^{+/+}$- Clozapine 5 mg/kg:Htr2a ${ }^{+/+}$ & 218.9879 & -220.814 & \\
\hline & & & Clozapine 0 mg/kg:Htr2a ${ }^{+/+}$- Clozapine 20 mg/kg:Htr2a ${ }^{+/+}$ & -112.395 & -533.474 & \\
\hline & & & Clozapine 0 mg/kg:Htr2a ${ }^{-/-}$- Clozapine 5 mg/kg:Htr2a ${ }^{-/-}$ & 207.5292 & -199.648 & \\
\hline & & & Clozapine 0 mg/kg:Htr2a ${ }^{-/-}$- Clozapine 20 mg/kg:Htr2a ${ }^{-/-}$ & -56.0882 & -477.167 & \\
\hline & & & Clozapine 5 mg/kg:Htr2a ${ }^{+/+}$- Clozapine 5 mg/kg:Htr2a ${ }^{-/-}$ & 228.0091 & -179.169 & \\
\hline & & & Clozapine $20 \mathrm{mg} / \mathrm{kg}: \mathrm{Htr} 2 \mathrm{a}^{+/+}-$Clozapine $20 \mathrm{mg} / \mathrm{kg}: \mathrm{Htr} 2 \mathrm{a}^{-/-}$ & 276.6153 & -124.867 & \\
\hline \multirow[t]{7}{*}{$4 B$, pir } & Normal & Two-way ANOVA & Clozapine 0 mg/kg:Htr2a ${ }^{+/+}$- Clozapine 0 mg/kg:Htr2a ${ }^{-/-}$ & 222.2253 & -138.417 & \\
\hline & & & Clozapine 0 mg/kg:Htr2a ${ }^{+/+}-$Clozapine 5 mg/kg:Htr2a ${ }^{+/+}$ & 162.3596 & -198.282 & \\
\hline & & & Clozapine 0 mg/kg:Htr2a ${ }^{+/+}$- Clozapine 20 mg/kg:Htr2a ${ }^{+/+}$ & -102.107 & -447.395 & \\
\hline & & & Clozapine 0 mg/kg:Htr2a ${ }^{-/-}$- Clozapine 5 mg/kg:Htr2a ${ }^{-/-}$ & 152.3912 & -192.897 & \\
\hline & & & Clozapine 0 mg/kg:Htr2a ${ }^{-/-}$- Clozapine 20 mg/kg:Htr2a ${ }^{-/-}$ & -60.0426 & -405.331 & \\
\hline & & & Clozapine 5 mg/kg:Htr2a ${ }^{+/+}-$Clozapine 5 mg/kg:Htr2a & 212.2569 & -133.031 & \\
\hline & & & Clozapine $20 \mathrm{mg} / \mathrm{kg}: \mathrm{Htr} 2 \mathrm{a}^{+/+}$- Clozapine $20 \mathrm{mg} / \mathrm{kg}: \mathrm{Htr} 2 \mathrm{a}^{-/-}$ & 248.5787 & -80.6407 & \\
\hline $4 C, \mathrm{cg}$ & Normal & Two-way ANOVA & Clozapine 0 mg/kg:Htr2a ${ }^{+/+}$- Clozapine 0 mg/kg:Htr2a ${ }^{-/-}$ & 202.757 & -223.344 & \\
\hline & & & Clozapine 0 mg/kg:Htr2a ${ }^{+/+}-$Clozapine 5 mg/kg:Htr2a ${ }^{+/+}$ & 235.1579 & -190.943 & \\
\hline & & & Clozapine 0 mg/kg:Htr2a ${ }^{+/+}$- Clozapine 20 mg/kg:Htr2a ${ }^{+/+}$ & -76.2599 & -484.22 & \\
\hline & & & Clozapine 0 mg/kg:Htr2a ${ }^{-/-}$- Clozapine 5 mg/kg:Htr2a ${ }^{-/-}$ & 214.9152 & -193.045 & \\
\hline & & & Clozapine 0 mg/kg:Htr2a ${ }^{-/-}$- Clozapine 20 mg/kg:Htr2a ${ }^{-/-}$ & -23.1811 & -449.282 & \\
\hline & & & Clozapine 5 mg/kg:Htr2a ${ }^{+/+}$- Clozapine 5 mg/kg:Htr2a ${ }^{-/-}$ & 182.5143 & -225.446 & \\
\hline & & & Clozapine 20 mg/kg:Htr2a $\mathrm{a}^{+/+}$- Clozapine 20 mg/kg:Htr2a ${ }^{-/-}$ & 237.6954 & -170.265 & \\
\hline $4 D, \mathrm{Vpm}$ & Normal & Two-way ANOVA & Clozapine 0 mg/kg:Htr2a ${ }^{+/+}$- Clozapine 0 mg/kg:Htr2a ${ }^{-/-}$ & 410.9157 & -303.868 & \\
\hline & & & Clozapine 0 mg/kg:Htr2a ${ }^{+/+}-$Clozapine 5 mg/kg:Htr2a ${ }^{+/+}$ & 235.4589 & -479.325 & \\
\hline & & & Clozapine 0 mg/kg:Htr2a ${ }^{+/+}$- Clozapine 20 mg/kg:Htr2a ${ }^{+/+}$ & -323.801 & -1038.59 & \\
\hline & & & Clozapine 0 mg/kg:Htr2a ${ }^{-/-}$- Clozapine 5 mg/kg:Htr2a ${ }^{-/-}$ & 289.2806 & -372.481 & \\
\hline & & & Clozapine 0 mg/kg:Htr2a ${ }^{-/-}$- Clozapine 20 mg/kg:Htr2a ${ }^{-/-}$ & -149.546 & -833.899 & \\
\hline & & & Clozapine 5 mg/kg:Htr2a ${ }^{+/+}-$Clozapine 5 mg/kg:Htr2a & 464.7374 & -197.024 & \\
\hline & & & $\begin{array}{l}\text { Clozapine } 20 \mathrm{mg} / \mathrm{kg}: \mathrm{Htr} 2 \mathrm{a}^{+/+} \text {- Clozapine } 20 \mathrm{mg} / \mathrm{kg}: \mathrm{Htr}_{2} \mathrm{a}^{-/-} \\
\text {(Continued) }\end{array}$ & 585.1711 & -99.1824 & \\
\hline
\end{tabular}


Table 1: Table of statistics

\begin{tabular}{lll}
\hline Figure & Data structure & Type of test \\
$5 C$, Ven & Normal & Two-way ANOVA
\end{tabular}

Confidence interval

Clozapine $0 \mathrm{mg} / \mathrm{kg}: \mathrm{Htr} 2 \mathrm{a}^{+/+}$- Clozapine $0 \mathrm{mg} / \mathrm{kg}: \mathrm{Htr}_{2 \mathrm{a}^{-/}}$ Clozapine 0 mg/kg:Htr2a ${ }^{+/+}$- Clozapine $5 \mathrm{mg} / \mathrm{kg}: \mathrm{Htr} \mathrm{a}^{+/+}$

Clozapine $0 \mathrm{mg} / \mathrm{kg}: \mathrm{Htr} 2 \mathrm{a}^{+/+}$- Clozapine $20 \mathrm{mg} / \mathrm{kg}: \mathrm{Htr} \mathrm{a}^{+/+}$ Clozapine $0 \mathrm{mg} / \mathrm{kg}: \mathrm{Htr} 2 \mathrm{a}^{-/-}$- Clozapine $5 \mathrm{mg} / \mathrm{kg}: \mathrm{Htr} 2 \mathrm{a}^{-/-}$

Clozapine $0 \mathrm{mg} / \mathrm{kg}: \mathrm{Htr} 2 \mathrm{a}^{-/-}$- Clozapine $20 \mathrm{mg} / \mathrm{kg}: \mathrm{Htr}_{2 \mathrm{a}}{ }^{-/-}$ Clozapine $5 \mathrm{mg} / \mathrm{kg}: \mathrm{Htr}_{2} \mathrm{a}^{+/+}$- Clozapine $5 \mathrm{mg} / \mathrm{kg}: \mathrm{Htr}_{2 \mathrm{a}} \mathrm{a}^{-/-}$

Clozapine $20 \mathrm{mg} / \mathrm{kg}: \mathrm{Htr} 2 \mathrm{a}^{+/+}$- Clozapine $20 \mathrm{mg} / \mathrm{kg}: \mathrm{Htr}_{2 a^{-/-}}$ Clozapine $0 \mathrm{mg} / \mathrm{kg}: \mathrm{Htr}_{2} \mathrm{a}^{+/+}$- Clozapine $0 \mathrm{mg} / \mathrm{kg}: \mathrm{Htr2a^{-/- }}$ Clozapine $0 \mathrm{mg} / \mathrm{kg}: \mathrm{Htr}_{2} \mathrm{a}^{+/+}$- Clozapine $5 \mathrm{mg} / \mathrm{kg}: \mathrm{Htr}_{2 \mathrm{a}}{ }^{+/+}$ Clozapine 0 mg/kg:Htr2a ${ }^{+/+}$- Clozapine $20 \mathrm{mg} / \mathrm{kg}: \mathrm{Htr}_{2} \mathrm{a}^{+/}$ Clozapine $0 \mathrm{mg} / \mathrm{kg}: \mathrm{Htr} 2 \mathrm{a}^{-/-}$- Clozapine $5 \mathrm{mg} / \mathrm{kg}: \mathrm{Htr} 2 \mathrm{a}^{-/-}$ Clozapine $0 \mathrm{mg} / \mathrm{kg}: \mathrm{Htr} 2 \mathrm{a}^{-/-}$- Clozapine $20 \mathrm{mg} / \mathrm{kg}: \mathrm{Htr}_{\mathrm{H}} \mathrm{a}^{-/-}$ Clozapine $5 \mathrm{mg} / \mathrm{kg}: \mathrm{Htr}_{2 \mathrm{a}}{ }^{+/+}$- Clozapine $5 \mathrm{mg} / \mathrm{kg}: \mathrm{Htr} 2 \mathrm{a}^{-/-}$ Clozapine $20 \mathrm{mg} / \mathrm{kg}: \mathrm{Htr}_{2} \mathrm{a}^{+/+}$- Clozapine $20 \mathrm{mg} / \mathrm{kg}: \mathrm{Htr}_{2} \mathrm{a}^{-/-}$

\begin{tabular}{|c|c|c|c|c|}
\hline \multirow[t]{6}{*}{ Extended Data Fig. 2-1A } & Not normal & Mann-Whitney test & Orb & $\begin{array}{l}\text { Clozapine } 5 \mathrm{mg} / \mathrm{kg} \text {, male } \\
\text { Clozapine } 5 \mathrm{mg} / \mathrm{kg} \text {, female }\end{array}$ \\
\hline & Normal & $t$ test with Welch's correction & Pir & $\begin{array}{l}\text { Clozapine } 5 \mathrm{mg} / \mathrm{kg} \text {, male } \\
\text { Clozapine } 5 \mathrm{mg} / \mathrm{kg} \text {, female }\end{array}$ \\
\hline & Not normal & Mann-Whitney test & $\mathrm{Cpu}$ & $\begin{array}{l}\text { Clozapine } 5 \mathrm{mg} / \mathrm{kg} \text {, male } \\
\text { Clozapine } 5 \mathrm{mg} / \mathrm{kg} \text {, female }\end{array}$ \\
\hline & Not normal & Mann-Whitney test & $\mathrm{Cg}$ & $\begin{array}{l}\text { Clozapine } 5 \mathrm{mg} / \mathrm{kg} \text {, male } \\
\text { Clozapine } 5 \mathrm{mg} / \mathrm{kg} \text {, female }\end{array}$ \\
\hline & Not normal & Mann-Whitney test & Vpm & $\begin{array}{l}\text { Clozapine } 5 \mathrm{mg} / \mathrm{kg} \text {, male } \\
\text { Clozapine } 5 \mathrm{mg} / \mathrm{kg} \text {, female }\end{array}$ \\
\hline & Normal & $t$ test with Welch's correction & Ven & $\begin{array}{l}\text { Clozapine } 5 \mathrm{mg} / \mathrm{kg} \text {, male } \\
\text { Clozapine } 5 \mathrm{mg} / \mathrm{kg} \text {, female }\end{array}$ \\
\hline \multirow[t]{6}{*}{ Extended Data Fig. $2-1 B$} & Normal & $t$ test with Welch's correction & Orb & $\begin{array}{l}\text { Clozapine } 0 \mathrm{mg} / \mathrm{kg} \text {, male } \\
\text { Clozapine } 0 \mathrm{mg} / \mathrm{kg} \text {, female }\end{array}$ \\
\hline & Normal & $t$ test with Welch's correction & Pir & $\begin{array}{l}\text { Clozapine } 0 \mathrm{mg} / \mathrm{kg} \text {, male } \\
\text { Clozapine } 0 \mathrm{mg} / \mathrm{kg} \text {, female }\end{array}$ \\
\hline & Not normal & Mann-Whitney test & Cpu & $\begin{array}{l}\text { Clozapine } 0 \mathrm{mg} / \mathrm{kg} \text {, male } \\
\text { Clozapine } 0 \mathrm{mg} / \mathrm{kg} \text {, female }\end{array}$ \\
\hline & Normal & $t$ test with Welch's correction & $\mathrm{Cg}$ & $\begin{array}{l}\text { Clozapine } 0 \mathrm{mg} / \mathrm{kg} \text {, male } \\
\text { Clozapine } 0 \mathrm{mg} / \mathrm{kg} \text {, female }\end{array}$ \\
\hline & Not normal & Mann-Whitney test & Vpm & $\begin{array}{l}\text { Clozapine } 0 \mathrm{mg} / \mathrm{kg} \text {, male } \\
\text { Clozapine } 0 \mathrm{mg} / \mathrm{kg} \text {, female }\end{array}$ \\
\hline & Normal & $t$ test with Welch's correction & Ven & $\begin{array}{l}\text { Clozapine } 5 \mathrm{mg} / \mathrm{kg} \text {, male } \\
\text { Clozapine } 5 \mathrm{mg} / \mathrm{kg} \text {, female }\end{array}$ \\
\hline \multirow[t]{4}{*}{ Extended Data Fig. 2-1C } & Normal & One-way ANOVA & Orb & $\begin{array}{l}\text { Vehicle - Clozapine } 5 \mathrm{mg} / \mathrm{kg} \\
\text { Vehicle - Clozapine } 20 \mathrm{mg} / \mathrm{kg}\end{array}$ \\
\hline & Normal & One-way ANOVA & Pir & $\begin{array}{l}\text { Vehicle - Clozapine } 5 \mathrm{mg} / \mathrm{kg} \\
\text { Vehicle - Clozapine } 20 \mathrm{mg} / \mathrm{kg}\end{array}$ \\
\hline & Normal & One-way ANOVA & $\mathrm{Cg}$ & $\begin{array}{l}\text { Vehicle - Clozapine } 5 \mathrm{mg} / \mathrm{kg} \\
\text { Vehicle - Clozapine } 20 \mathrm{mg} / \mathrm{kg}\end{array}$ \\
\hline & Normal & One-way ANOVA & Vpm & $\begin{array}{l}\text { Vehicle - Clozapine } 5 \mathrm{mg} / \mathrm{kg} \\
\text { Vehicle - Clozapine } 20 \mathrm{mg} / \mathrm{kg}\end{array}$ \\
\hline
\end{tabular}

\begin{tabular}{|c|c|c|}
\hline Upper & Lower & Mean ran \\
\hline 1303.436 & -1218.51 & \\
\hline-718.805 & -3133.38 & \\
\hline-894.704 & -3309.28 & \\
\hline 968.4059 & -1366.46 & \\
\hline-352.59 & -2767.17 & \\
\hline 2878.763 & 660.2965 & \\
\hline 1735.683 & -566.528 & \\
\hline 2383.313 & -2281.76 & \\
\hline-414.784 & -4881.25 & \\
\hline-1362.27 & -6027.34 & \\
\hline 1852.895 & -2613.57 & \\
\hline-265.062 & -4930.13 & \\
\hline 4447.76 & 189.1545 & \\
\hline \multirow[t]{3}{*}{3480.52} & -1184.55 & \\
\hline & & 6 \\
\hline & & 6 \\
\hline 170.4 & 282.1 & \\
\hline \multirow[t]{7}{*}{80.06} & 433.9 & \\
\hline & & 5 \\
\hline & & 3.25 \\
\hline & & 4 \\
\hline & & 4.8 \\
\hline & & 6.25 \\
\hline & & 5 \\
\hline 1810 & 3086 & \\
\hline 1728 & 2991 & \\
\hline 43.25 & 82.37 & \\
\hline 33.38 & 60.78 & \\
\hline 51.08 & 105.4 & \\
\hline \multirow[t]{3}{*}{49.77} & 91.82 & \\
\hline & & 3.375 \\
\hline & & 6.3 \\
\hline 42.15 & 103.2 & \\
\hline \multirow[t]{3}{*}{39.36} & 94.81 & \\
\hline & & 7.4 \\
\hline & & 5.857 \\
\hline 196.1 & 298.8 & \\
\hline 176.8 & 319.8 & \\
\hline 47.26361 & -237.813 & \\
\hline-93.267 & -328.661 & \\
\hline 30.72838 & -159.372 & \\
\hline-89.141 & -243.332 & \\
\hline 37.98281 & -263.291 & \\
\hline-35.4183 & -304.886 & \\
\hline-31.2811 & -302.009 & \\
\hline-173.181 & -410.795 & \\
\hline
\end{tabular}

expressing" Paneth cells in providing the niche for intestinal stem cells (Sato et al., 2011).

In Clozapine-induced dose response, most brain areas did not show significant $c$-fos activity at the lower dose of $5 \mathrm{mg} / \mathrm{kg}$. However, strikingly large number of ependymal cells showed response even at the lowest dose of Clozapine, i.e., $5 \mathrm{mg} / \mathrm{kg}$. This would indicate that ependymal cells are more sensitive to Clozapine than cells in other brain areas that we examined.

Additionally, serotonin has been shown to increase ciliary beat frequency, which can be blocked by the broad spectrum $5-\mathrm{HT}_{2}$ receptor antagonist, mianserin (Nguyen et al., 2001). Therefore, the interaction of antipsychotics with the ependymal cells may regulate ciliary beat frequency and in turn the flow of CSF and transport of molecules through CSF. Also, it is important to note that we cannot exclude the involvement of the activated ependymal cells in the side effects of antipsychotics rather than the therapeutic effects.
Clozapine-induced c-fos activity in the ependymal cells was absent in the $\mathrm{Htr}_{\mathrm{r}} \mathrm{a}^{-/-}$mice at $5 \mathrm{mg} / \mathrm{kg}$. Interestingly, $c$-fos activity is regained when the dose of Clozapine is increased to $20 \mathrm{mg} / \mathrm{kg}$, suggesting that $5-\mathrm{HT}_{2 \mathrm{~A}}$ facilitates the activation of ependymal cells in response to Clozapine at the lower doses and the Htr2a $\mathrm{a}^{-/-}$mice should serve to ascertain other pathways that may be also involved when Clozapine is present at higher concentrations.

" $5-\mathrm{HT}_{2 \mathrm{~A}}$ independent" pathway of antipsychoticinduced activation of the ependymal cell would be of interest to pursue. Most antipsychotics, have a broad spectrum of GPCR targets (Roth et al., 2004). Therefore, systematic comparison of the differences in receptor binding profile of the four antipsychotics that we tested, can reveal interesting candidates such as the histamine receptor H1 (Roth et al., 2004). Incidentally, histamine has been shown to increase c-Fos immunoreactivity in the ependymal cells (Palkovits et al., 2007). Dopamine receptors and other 5-HT receptors would also be the other 
candidates and interestingly enough, 5-HT6 receptor and dopamine receptors (D1, D2, and D5) are reported to localize to primary cilia (Marley and von Zastrow, 2010; Hu et al., 2017). One has to also keep "functional selectivity" in mind, i.e., when GPCRs interact with different antipsychotics (Yadav et al., 2011b; Raote et al., 2013). Importantly, the $5-\mathrm{HT}_{2 \mathrm{~A}}$-independent pathway of activation of ependymal cells could be GPCR independent and be regulated by the other intracellular targets of antipsychotics instead (Yadav et al., 2011a).

It is also important to keep certain limitations of this study in mind. Firstly, we have used WT or Htr2a $\mathrm{a}^{-/-}$mice, which by themselves are clearly not a model for psychosis. We have so far only looked at the acute effects of the antipsychotic treatment. Antipsychotic treatments in patients are typically chronic and therapeutic effects often begin to appear later in the treatment, whereas some side effects do appear in the early part of the treatment. Therefore, it is important to compare both the acute and chronic patterns of antipsychotic activity. The patterns of activity observed by us may also be limited by the differences in the efficiency of "TRAP" in different neural subtypes or brain regions. Variation in efficiencies can in part address the lack of antipsychotic-induced c-fos activity in the nucleus accumbens and medial prefrontal cortex, which have been reported as the targets of antipsychotics earlier.

Nonetheless, the TRAP system has allowed us to reexamine antipsychotic-induced patterns of activity in the brain and led to the identification of novel targets. Trap system provides distinct advantages over the existing methods: (1) better visualization of cellular morphology and potential connectivity; (2) permanent marking/labeling of the cells; and (3) killing of the animals immediately after the stimulus is not required.

This approach can also be extended with the optogenetic and biochemical techniques to shed light on the physiologic role of various cell types and brain areas in the functioning of antipsychotic drugs in detail and also can be extended to other genes.

\section{References}

Ahlqvist J, Isacson R, Wahlestedt C, Salmi P (2003) Anti-cataleptic effects of clozapine, but not olanzapine and quetiapine, on $\mathrm{SCH}$ 23390- or raclopride-induced catalepsy in rats. Eur Neuropsychopharmacol 13:177-182. Medline

Ansah TA, Ferguson MC, Nayyar T (2011) The 5-HT(2A) receptor antagonist M100907 produces antiparkinsonian effects and decreases striatal glutamate. Front Syst Neurosci 5:48. CrossRef Medline

Badiani A, Oates MM, Day HE, Watson SJ, Akil H, Robinson TE (1999) Environmental modulation of amphetamine-induced c-fos expression in D1 versus D2 striatal neurons. Behav Brain Res 103:203-209. Medline

Barbey AK, Koenigs M, Grafman J (2011) Orbitofrontal contributions to human working memory. Cereb Cortex 21:789-795. CrossRef Medline

Bortolozzi A, Masana M, Díaz-Mataix L, Cortés R, Scorza MC, Gingrich JA, Toth M, Artigas F (2010) Dopamine release induced by atypical antipsychotics in prefrontal cortex requires $5-\mathrm{HT} 1 \mathrm{~A}$ receptors but not 5-HT2A receptors. Int J Neuropsychopharmacol 13:1299-1314. CrossRef
Brightman MW, Palay SL (1963) The fine structure of ependyma in the brain of the rat. J Cell Biol 19:415-439. Medline

Bruni JE (1998) Ependymal development, proliferation, and functions: a review. Microsc Res Tech 41:2-13. CrossRef Medline

Cohen M (1995) The Thalamus as a Site of Action of Antipsychotic Drugs. Am J Psychiatry 153:104-106. CrossRef Medline

Cope MB, Nagy TR, Fernández JR, Geary N, Casey DE, Allison DB (2005) Antipsychotic drug-induced weight gain: development of an animal model. Int J Obes (Lond) 29:607-614. CrossRef Medline

Creed-Carson M, Oraha A, Nobrega JN (2011) Effects of 5-HT(2A) and $5-\mathrm{HT}(2 \mathrm{C})$ receptor antagonists on acute and chronic dyskinetic effects induced by haloperidol in rats. Behav Brain Res 219:273-279. CrossRef Medline

Day HE, Badiani A, Uslaner JM, Oates MM, Vittoz NM, Robinson TE, Watson SJ, Akil H (2001) Environmental novelty differentially affects c-fos mRNA expression induced by amphetamine or cocaine in subregions of the bed nucleus of the stria terminalis and amygdala. J Neurosci 21:732-740. Medline

Del Bigio MR (1995) The ependyma: a protective barrier between brain and cerebrospinal fluid. Glia 14:1-13. CrossRef Medline

Deutch AY, Duman RS (1996) The effect of antipsychotic drugs on Fos protein expression in the prefrontal cortex-cellular localization and pharmacological characterization. Neuroscience 70:377-389. CrossRef

Deutch AY, Ongur D, Duman RS (1995) Antipsychotic drugs induce Fos protein in the thalamic paraventricular nucleus: a novel locus of antipsychotic drug action. Neuroscience 66:337-346. CrossRef Didier M, Harandi M, Aguera M, Bancel B, Tardy M, Fages C, Calas A, Stagaard M, Møllgård K, Belin MF (1986) Differential immunocytochemical staining for glial fibrillary acidic (GFA) protein, S-100 protein and glutamine synthetase in the rat subcommissural organ, nonspecialized ventricular ependyma and adjacent neuropil. Cell Tissue Res 245:343-351. Medline

Dragunow M, Faull RLM (1989) Rolipram induces c-fos protein-like immunoreactivity in ependymal and glial-like cells in adult rat brain. Brain Res 501:382-388.

Fornito A, Yücel M, Dean B, Wood SJ, Pantelis C (2009) Anatomical abnormalities of the anterior cingulate cortex in schizophrenia: bridging the gap between neuroimaging and neuropathology. Schizophr Bull 35:973-993. CrossRef Medline

Fribourg M, Moreno JL, Holloway T, Provasi D, Baki L, Mahajan R, Park G, Adney SK, Hatcher C, Eltit JM, Ruta JD, Albizu L, Li Z, Umali A, Shim J, Fabiato A, MacKerell AD Jr, Brezina V, Sealfon SC, Filizola M, et al. (2011) Decoding the signaling of a GPCR heteromeric complex reveals a unifying mechanism of action of antipsychotic drugs. Cell 147:1011-1023.

González-Maeso J, Yuen T, Ebersole BJ, Wurmbach E, Lira A, Zhou M, Weisstaub N, Hen R, Gingrich JA, Sealfon SC (2003) Transcriptome fingerprints distinguish hallucinogenic and nonhallucinogenic 5-hydroxytryptamine $2 \mathrm{~A}$ receptor agonist effects in mouse somatosensory cortex. J Neurosci 23:8836-8843. Medline

González-Maeso J, Ang RL, Yuen T, Chan P, Weisstaub NV, LópezGiménez JF, Zhou M, Okawa Y, Callado LF, Milligan G, Gingrich JA, Filizola M, Meana JJ, Sealfon SC (2008) Identification of a serotonin/glutamate receptor complex implicated in psychosis. Nature 452:93-97. CrossRef Medline

Guenthner C, Miyamichi K, Yang HH, Heller HC, Luo L (2013) Permanent genetic access to transiently active neurons via TRAP: targeted recombination in active populations. Neuron 78:773-784. CrossRef Medline

Gunn AJ, Dragunow M, Faull RL, Gluckman PD (1990) Effects of hypoxia-ischemia and seizures on neuronal and glial-like c-fos protein levels in the infant rat. Brain Res 531:105-116. Medline

Halim ND, Weickert CS, Mcclintock BW, Weinberger DR, Lipska BK (2004) Effects of chronic haloperidol and clozapine treatment on neurogenesis in the adult rat hippocampus. Neuropsychopharmacology 29:1063-1069. CrossRef

Hippius H (1989) The history of clozapine. Psychopharmacology (Berl) 99:S3-S5. CrossRef 
Hu L, Wang B, Zhang Y (2017) Serotonin 5-HT6 receptors affect cognition in a mouse model of Alzheimer's disease by regulating cilia function. Alzheimers Res Ther 9:76.

Jiménez AJ, Domínguez-Pinos M-D, Guerra MM, Fernández-Llebrez P, Pérez-Fígares J-M (2014) Structure and function of the ependymal barrier and diseases associated with ependyma disruption. Tissue Barriers 2:e28426. CrossRef Medline

Joshi RS, Quadros R, Drumm M, Ain R, Panicker MM (2017) Sedative effect of clozapine is a function of 5-HT2A and environmental novelty. Eur Neuropsychopharmacol 27:70-81.

Kalkman HO, Neumann V, Tricklebank MD (1997) Clozapine inhibits catalepsy induced by olanzapine and loxapine, but prolongs catalepsy induced by SCH 23390 in rats. Naunyn Schmiedebergs Arch Pharmacol 355:361-364. Medline

Kapur S, Remington G, Zipursky RB, Wilson AA, Houle S (1995) The D2 dopamine receptor occupancy of risperidone and its relationship to extrapyramidal symptoms: a pet study. Life Sci 57:PL103PL107.

Kapur S, Zipursky R, Jones C, Remington G, Houle S (2000) Relationship between dopamine $\mathrm{D}(2)$ occupancy, clinical response, and side effects: a double-blind PET study of first-episode schizophrenia. Am J Psychiatry 157:514-520. CrossRef Medline

Kodama M, Fujioka T, Duman RS (2004) Chronic olanzapine or fluoxetine administration increases cell proliferation in hippocampus and prefrontal cortex of adult rat. Biol Psychiatry 56:570-580. CrossRef Medline

Lee JE, Gleeson JG (2011) Cilia in the nervous system: linking cilia function and neurodevelopmental disorders. Curr Opin Neurol 24:98-105. CrossRef Medline

Leucht S, Corves C, Arbter D, Engel RR, Li C, Davis JM (2009) Second-generation versus first-generation antipsychotic drugs for schizophrenia: a meta-analysis. Lancet 373:31-41. CrossRef Medline

Lim DA, Tramontin AD, Trevejo JM, Herrera DG, García-Verdugo JM, Alvarez-Buylla A (2000) Noggin antagonizes BMP signaling to create a niche for adult neurogenesis. Neuron 28:713-726. Medline

Luo J, Shook BA, Daniels SB, Conover JC (2008) Subventricular zone-mediated ependyma repair in the adult mammalian brain. $\mathrm{J}$ Neurosci 28:3804-3813. CrossRef Medline

Marley A, von Zastrow M (2010) DISC1 regulates primary cilia that display specific dopamine receptors. PLoS One 5:e10902. CrossRef Medline

Marley A, von Zastrow M (2012) A simple cell-based assay reveals that diverse neuropsychiatric risk genes converge on primary cilia. PLoS One 7:e46647. CrossRef Medline

McOmish CE, Lira A, Hanks JB, Gingrich JA (2012) Clozapineinduced locomotor suppression is mediated by $5-\mathrm{HT} 2 \mathrm{~A}$ receptors in the forebrain. Neuropsychopharmacology 37:2747-2755. CrossRef Medline

Meltzer HY, Matsubara S, Lee JC (1989) Classification of typical and atypical antipsychotic drugs on the basis of dopamine D-1, D-2 and serotonin2 pKi values. J Pharmacol Exp Ther 251:238-246. Medline

Miner LAH, Backstrom JR, Sanders-Bush E, Sesack SR (2003) UItrastructural localization of serotonin2A receptors in the middle layers of the rat prelimbic prefrontal cortex. Neuroscience 116: 107-117. CrossRef

Moberg P, Agrin R, Gur RE, Gur RC, Turetsky BI, Doty RL (1999) Olfactory dysfunction in schizophrenia: a qualitative and quantitative review. Neuropsychopharmacology 21:325-340. CrossRef Medline

Moreno JL, Miranda-Azpiazu P, García-Bea A, Younkin J, Cui M, Kozlenkov A, Ben-Ezra A, Voloudakis G, Fakira AK, Baki L, Ge Y, Georgakopoulos A, Morón JA, Milligan G, López-Giménez JF, Robakis NK, Logothetis DE, Meana JJ, González-Maeso J (2016) Allosteric signaling through an mGlu2 and 5-HT2A heteromeric receptor complex and its potential contribution to schizophrenia. Sci Signal 9:ra5. CrossRef Medline
Morgan J, Cohen D, Hempstead J, Curran T (1987) Mapping patterns of c-fos expression in the central nervous system after seizure. Science 237:192-197.

Muguruza C, Moreno JL, Umali A, Callado LF, Meana JJ, GonzálezMaeso J (2013) Dysregulated 5-HT(2A) receptor binding in postmortem frontal cortex of schizophrenic subjects. Eur Neuropsychopharmacol 23:852-864. CrossRef Medline

Nelson BDJ, Wright EM (1974) The distribution, activity, and function of cilia in the frog brain. J Physiol 63-78. CrossRef

Nguyen T, Chin WC, O’Brien JA, Verdugo P, Berger AJ (2001) Intracellular pathways regulating ciliary beating of rat brain ependymal cells. J Physiol 531:131-140. CrossRef

Nielsen S, Nagelhus EA, Amiry-Moghaddam M, Bourque C, Agre P, Petter Ottersen O (1997) Specialized membrane domains for water transport in glial cells: high-resolution immunogold cytochemistry of aquaporin-4 in rat brain. J Neurosci 17:171-180. CrossRef

Ohashi K, Hamamura T, Lee Y, Fujiwara Y, Suzuki H, Kuroda S (2000) Clozapine- and olanzapine-induced Fos expression in the rat medial prefrontal cortex is mediated by $\beta$-adrenoceptors. Neuropsychopharmacology 23:162-169. CrossRef Medline

Ostrander M, Badiani A, Day HE, Norton C, Watson S, Akil H, Robinson T (2003) Environmental context and drug history modulate amphetamine-induced c-fos mrna expression in the basal ganglia, central extended amygdala, and associated limbic forebrain. Neuroscience 120:551-571. Medline

Palkovits M, Deli MA, Gallatz K, Tóth ZE, Buzás E, Falus A (2007) Highly activated $\mathrm{C}$-fos expression in specific brain regions (ependyma, circumventricular organs, choroid plexus) of histidine decarboxylase deficient mice in response to formalin-induced acute pain. Neuropharmacology 53:101-112. CrossRef Medline

Pantelis C, Velakoulis D, McGorry PD, Wood SJ, Suckling J, Phillips LJ, Yung AR, Bullmore ET, Brewer W, Soulsby B, Desmond P, McGuire PK (2003) Neuroanatomical abnormalities before and after onset of psychosis: a cross-sectional and longitudinal MRI comparison. Lancet 361:281-288. CrossRef Medline

Rajkumar R, See LKY, Dawe GS (2013) Acute antipsychotic treatments induce distinct c-Fos expression patterns in appetiterelated neuronal structures of the rat brain. Brain Res 1508:34-43. CrossRef

Raote I, Bhattacharyya S, Panicker MM (2013) Functional selectivity in serotonin receptor $2 \mathrm{~A}$ (5-HT 2A). Mol Pharmac 83:42-50. CrossRef Medline

Robertson GS, Fibiger HC (1996) Effects of olanzapine on regional c-Fos expression in rat forebrain. Neuropsychopharmacology 14: 105-110.

Ross CA, Margolis RL, Reading SAJ, Pletnikov M, Coyle JT (2006) Neurobiology of schizophrenia. Neuron 52:139-153. CrossRef Medline

Roth BL, Craigo SC, Choudhary MS, Uluer A, Monsma FJ, Shen Y, Meltzer HY, Sibley DR (1994) Binding of typical and atypical antipsychotic agents to 5-hydroxytryptamine-6 and 5-hydroxytryptamine-7 receptors. J Pharmacol Exp Ther 268:1403-1410.

Roth BL, Sheffler DJ, Kroeze WK (2004) Magic shotguns versus magic bullets: selectively non-selective drugs for mood disorders and schizophrenia. Nat Rev Drug Discov 3:353-359. CrossRef Medline

Rushworth MFS, Noonan MP, Boorman ED, Walton ME, Behrens TE (2011) Frontal cortex and reward-guided learning and decisionmaking. Neuron 70:1054-1069. CrossRef

Sato T, Van Es JH, Snippert HJ, Stange DE, Vries RG, Van Den Born M, Barker N, Shroyer NF, Van De Wetering M, Clevers H (2011) Paneth cells constitute the niche for Lgr5 stem cells in intestinal crypts. Nature 469:415-418. CrossRef Medline

Schmid CL, Streicher JM, Meltzer HY, Bohn LM (2014) Clozapine acts as an agonist at serotonin $2 \mathrm{~A}$ receptors to counter MK-801induced behaviors through a $\beta$ arrestin2-independent activation of Akt. Neuropsychopharmacology 39:1902-1913. CrossRef Medline

Schnitzer J, Franke W, Schachner M (1981) Immunocytochemical demonstration of vimentin in astrocytes and ependymal cells of 
developing and adult mouse nervous system. J Cell Biol 90:435447.

Shen W (1992) A history of antipsychotic drug development. Compr Psychiatry 33:147-151.

Sheng M, McFadden G, Greenberg ME (1990) Membrane depolarization and calcium induce c-fos transcription via phosphorylation of transcription factor CREB. Neuron 4:571-582. Medline

Sibille E, Sarnyai Z, Benjamin D, Gal J, Baker H, Toth M (1997) Antisense inhibition of 5-hydroxytryptamine 2a receptor induces an antidepressant-like effect in mice. Mol Pharmacol 52:10561063. CrossRef

Tissir F, Qu Y, Montcouquiol M, Zhou L, Komatsu K, Shi D, Fujimori T, Labeau J, Tyteca D, Courtoy P, Poumay Y, Uemura T, Goffinet AM (2010) Lack of cadherins Celsr2 and Celsr3 impairs ependymal ciliogenesis, leading to fatal hydrocephalus. Nat Neurosci 13:700707. CrossRef Medline

Tramontin AD, García-Verdugo JM, Lim DA, Alvarez-Buylla A (2003) Postnatal development of radial glia and the ventricular zone (VZ): a continuum of the neural stem cell compartment. Cereb Cortex 13:580-587. Medline

Turetsky BI, Moberg PJ, Yousem DM, Doty RL, Arnold SE, Gur RE (2000) Reduced olfactory bulb volume in patients with schizophrenia. Am J Psychiatry 157:828-830. CrossRef Medline

Uslaner J, Badiani A, Day HE, Watson SJ, Akil H, Robinson TE (2001) Environmental context modulates the ability of cocaine and amphetamine to induce c-fos mRNA expression in the neocortex, caudate nucleus, and nucleus accumbens. Brain Res 920:106116. Medline

Verma V, Lim EP, Han SP, Nagarajah R, Dawe GS (2007) Chronic high-dose haloperidol has qualitatively similar effects to risperidone and clozapine on immediate-early gene and tyrosine hydroxylase expression in the rat locus coeruleus but not medial prefrontal cortex. Neurosci Res 57:17-28. CrossRef
Wadenberg M-LG, Kapur S, Soliman A, Jones C, Vaccarino F (2000) Dopamine $D 2$ receptor occupancy predicts catalepsy and the suppression of conditioned avoidance response behavior in rats. Psychopharmacology (Berl) 150:422-429. CrossRef

Wakade CG, Mahadik SP, Waller JL, Chiu F-C (2002) Atypical neuroleptics stimulate neurogenesis in adult rat brain. J Neurosci Res 69:72-79. CrossRef

Wan W, Ennulat DJ, Cohen BM (1995) Acute administration of typical and atypical antipsychotic drugs induces distinctive patterns of Fos expression in the rat forebrain. Brain Res 688:95104. Medline

Wang HD, Dunnavant FD, Jarman T, Deutch AY (2004) Effects of antipsychotic drugs on neurogenesis in the forebrain of the adult rat. Neuropsychopharmacology 29:1230-1238. CrossRef Medline

Williams A. a, Ingram WM, Levine S, Resnik J, Kamel CM, Lish JR, Elizalde DI, Janowski S. a, Shoker J, Kozlenkov A, GonzálezMaeso J, Gallitano AL (2012) Reduced levels of serotonin 2A receptors underlie resistance of Egr3-deficient mice to locomotor suppression by clozapine. Neuropsychopharmacology 37:22852298. CrossRef Medline

Xu T, Pandey SC (2000) Cellular localization of serotonin2A (5HT2A) receptors in the rat brain. Brain Res Bull 51:499-505. Medline

Yadav PN, Abbas Al, Farrell MS, Setola V, Sciaky N, Huang X-P, Kroeze WK, Crawford LK, Piel D. a, Keiser MJ, Irwin JJ, Shoichet BK, Deneris ES, Gingrich J, Beck SG, Roth BL (2011a) The presynaptic component of the serotonergic system is required for clozapine's efficacy. Neuropsychopharmacology 36:638-51. CrossRef

Yadav PN, Kroeze WK, Farrell MS, Roth BL (2011b) Antagonist functional selectivity: 5-HT2A serotonin receptor antagonists differentially regulate 5-HT2A receptor protein level in vivo. J Pharmacol Exp Ther 339:99-105. CrossRef 